\title{
Discovering and Mapping the Modified Nucleotides That Comprise the Epitranscriptome of mRNA
}

\author{
Bastian Linder ${ }^{1,2}$ and Samie R. Jaffrey ${ }^{2}$ \\ ${ }^{1}$ Genome Biology Unit, European Molecular Biology Laboratory, Heidelberg 69117, Germany \\ ${ }^{2}$ Department of Pharmacology, Weill Cornell Medicine, New York, New York 10065 \\ Correspondence: srj2003@med.cornell.edu
}

\section{SUMMARY}

An important mechanism of gene expression regulation is the regulated modification of nucleotides in messenger RNA (mRNA). These modified nucleotides affect mRNA translation, stability, splicing, and other processes. A cluster of nucleotide modifications is found adjacent to the mRNA cap structure and another set can be found internally within transcripts. The most prominent modifications are methylations of adenosine to form either $N^{6}$-methyladenosine $\left(\mathrm{m}^{6} \mathrm{~A}\right)$, an internal modified nucleotide, or $N^{6}, 2^{\prime}-O$-dimethyladenosine $\left(\mathrm{m}^{6} \mathrm{Am}\right)$, which is found exclusively at the first templated nucleotide of certain mRNAs. In addition, other rare modified nucleotides have been identified and together these form the epitranscriptomic code of mRNA. In the case of some modified nucleotides, the presence, location, or abundance is a subject of debate. Here, we review the methods that enable the discovery of modified nucleotides and how these approaches can be used to map epitranscriptomic modifications in mRNA.

\section{Outline}

1 Introduction

2 The history of the detection of methylated nucleotides in mRNA

3 Advantages and challenges of biochemical methods

4 Next-generation sequencing-based technologies for mapping internal nucleotide modifications
5 Mapping the cap epitranscriptome

6 Concluding remarks and further directions

References 


\section{INTRODUCTION}

Chemically modified nucleotides were identified in messenger RNAs (mRNAs) more than 40 years ago. These modifications were found within the mRNA cap structure at the $5^{\prime}$ end of all mRNAs and as modifications of internal nucleotides. However, until recently these modifications were generally overlooked or thought to be constitutive modifications that occur during mRNA biogenesis. Only recently has it become clear that nucleotide modifications can be selectively distributed on specific mRNAs, can vary depending on disease state or cellular context, and are endowed with regulatory potential for mRNA stability, translation, splicing, localization, and other functions. These effects account for the ability of nucleotide modifications to affect diverse physiological and pathological processes such as differentiation, viral infection, and cancer progression (for recent reviews, see Gokhale and Horner 2017; Jaffrey and Kharas 2017; Klungland et al. 2017).

The reemergence of the concept of epitranscriptomic regulation (i.e., the idea that the number, location, and type of nucleotide modifications contain information that influences mRNA fate in cells) has been a consequence of new technologies that allow nucleotide modifications to be mapped throughout the transcriptome. The initial epitranscriptomic mapping studies developed by us and others focused on $N^{6}$-methyladenosine $\left(\mathrm{m}^{6} \mathrm{~A}\right)$ (Dominissini et al. 2012; Meyer et al. 2012) and showed the power of mapping technologies for revealing the dynamics of epitranscriptomic variation in diverse cellular conditions and disease states. Since that time, newer $\mathrm{m}^{6} \mathrm{~A}$-mapping methods have been introduced that provide single-nucleotide resolution $\mathrm{m}^{6} \mathrm{~A}$ maps of the transcriptome (Linder et al. 2015), enabling researchers to use mutagenesis to ascertain the function of specific $\mathrm{m}^{6} \mathrm{~A}$ residues in mRNA.

The studies on $\mathrm{m}^{6} \mathrm{~A}$ spurred researchers to discover additional modifications that comprise the epitranscriptomic code. Currently, the most abundant and well-documented modifications are $\mathrm{m}^{6} \mathrm{~A}, N^{6}, 2^{\prime}-O$-dimethyladenosine $\left(\mathrm{m}^{6} \mathrm{Am}\right)$, and pseudouridine. In the case of $\mathrm{m}^{6} \mathrm{~A}$, thousands of $\mathrm{m}^{6} \mathrm{~A}$ sites have been mapped in mRNA, with the number of sites depending on the study, cell type, and, most importantly, sensitivity of the assay for detecting low-stoichiometry modification sites. Other modifications have also been mapped in mRNA, including 5-methylcytidine $\left(\mathrm{m}^{5} \mathrm{C}\right), N^{1}$ methyladenosine $\left(\mathrm{m}^{1} \mathrm{~A}\right)$, and $2^{\prime}-O$-methylated nucleotides $\left(\mathrm{N}_{\mathrm{m}}\right)$. It should be noted that there has been some disagreement in the field regarding the abundance of these modifications, largely focusing on high false-positive rates in some of the mapping approaches for $\mathrm{m}^{5} \mathrm{C}, \mathrm{m}^{1} \mathrm{~A}$, and $\mathrm{N}_{\mathrm{m}}$ (Zaringhalam and Papavasiliou 2016; Legrand et al. 2017;
Grozhik and Jaffrey 2017). Additional work will be required to understand the prevalence of these modifications and the basis for the disagreements in the field.

Among the abundant modifications in mRNA, the only ones mapped to date are $\mathrm{m}^{6} \mathrm{~A}$ and $\mathrm{m}^{6} \mathrm{Am}$. Other modifications, especially at mRNA cap structures, are also abundant and may have regulatory potential. Currently, a major goal is to discover all the modifications that comprise the epitranscriptomic code and to develop techniques to map these modifications. Additionally, in many cases, mapping the known modifications can provide key insights into whether a signaling pathway or disease process involves epitranscriptomic regulation and if a specific mRNA of interest is potentially controlled by nucleotide modifications. Below, we describe how mRNA modifications are detected and localized throughout the transcriptome.

\section{THE HISTORY OF THE DETECTION OF METHYLATED NUCLEOTIDES IN mRNA}

So far, nine methylated nucleotides have been identified in mammalian mRNA (Fig. 1). Most of these methylated nucleotides were initially discovered in the 1970s when researchers were investigating the composition of the mRNA $5^{\prime}$ cap, which is now known to be an untemplated guanosine that is methylated to form 7 -methylguanosine $\left(m^{7} G\right) \cdot m^{7} G$ is linked to the first transcribed nucleotide by an unconventional $5^{\prime}-5^{\prime}$ triphosphate bond.

These experiments also led to the discovery of $\mathrm{m}^{6} \mathrm{~A}$. In contrast to $\mathrm{m}^{7} \mathrm{G}, \mathrm{m}^{6} \mathrm{~A}$ is an internal methylated nucleotide. In the experiments that led to the discovery of $\mathrm{m}^{6} \mathrm{~A}$, cells were metabolically labeled with $\left[{ }^{3} \mathrm{H}\right.$-methyl]-methionine, which allows methyl modifications in mRNA to be labeled. Hydrolysis of cellular poly(A) RNA revealed evidence of a methylated nucleotide, which was eventually determined to be $\mathrm{m}^{6} \mathrm{~A}$. Early biochemical studies found that as many as $0.5 \%$ of all adenosines in mRNAs are modified to $\mathrm{m}^{6} \mathrm{~A}$, with an average frequency of 1 to $5 \mathrm{~m}^{6} \mathrm{~A}$ nucleotides per capped mRNA molecule (Sommer et al. 1978).

Studies of the mRNA cap also led to the discovery of the 2'-O-methylated versions of $A, G, C$, and $U$, which are designated $A_{m}, G_{m}, C_{m}$, and $U_{m}$ ( jointly referred to as $N_{m}$ in this text). $N_{m}$ was identified as part of the "extended mRNA cap," which comprises the $\mathrm{m}^{7} \mathrm{G}$ and the first or the first two transcribed nucleotides. Labeling studies using $\left[{ }^{3} \mathrm{H}\right.$-methyl]-methionine as the radioactive methyl donor revealed that either the first or the first and second transcribed nucleotide can be methylated at the 2'-hydroxyl group of the ribose (Wei et al. 1975a). The corresponding extended cap structures are referred to as cap1 and cap2, respectively. Recent mapping studies have suggested that 


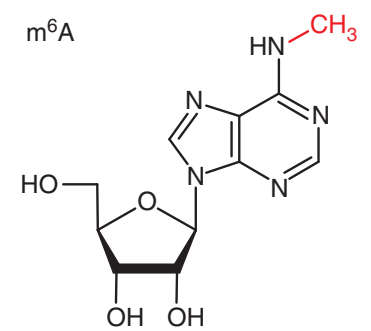<smiles>C[n+]1cnc2c(ncn2[C@@H]2O[C@H](CO)[C@@H](O)[C@H]2O)c1N</smiles><smiles>O=c1[nH]cc([C@@H]2O[C@H](CO)[C@@H](O)[C@H]2O)c(=O)[nH]1</smiles><smiles>Cc1cn([C@@H]2O[C@H](CO)[C@@H](O)[C@H]2O)c(=O)nc1N</smiles><smiles>Nc1nc(=O)n([C@@H]2O[C@H](CO)[C@@H](O)[C@H]2O)cc1CO</smiles>

$80 \times 0 G$

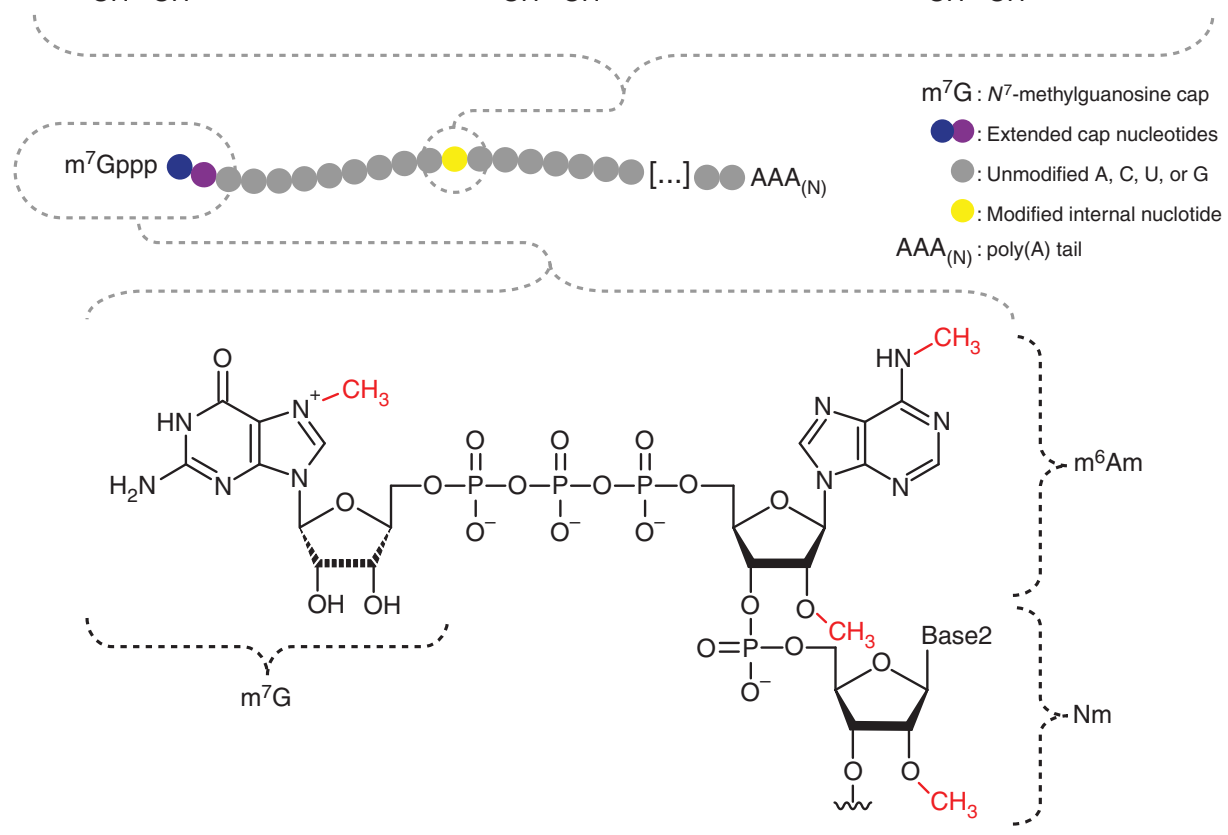

Figure 1. Modified nucleotides of eukaryotic messenger RNAs (mRNAs). (Upper panel) Structures of the six basemodified nucleotides identified in eukaryotic mRNA. $\mathrm{m}^{6} \mathrm{~A}, N^{6}$-methyladenosine; $\mathrm{m}^{1} \mathrm{~A}, N^{1}$-methyladenosine; $\mathrm{m}^{5} \mathrm{C}$, 5-methylcytidine; $\mathrm{hm}^{5} \mathrm{C}$, 5-hydroxymethylcytidine; 8-oxoG, 8-oxoguanosine. Chemical groups that have been added to or isomerized in canonical nucleotides are indicated in red. (Middle panel) Schematic of a modified mRNA molecule. The $\mathrm{m}^{7} \mathrm{G}$ cap with its unusual $5^{\prime}-5^{\prime}$-triphosphate bond and the poly(A) tail are indicated. Unmodified nucleotides are represented as gray beads. Modified first and second nucleotides are indicated in blue and purple, respectively. Internal modifications are indicated in yellow. (Lower panel) The extended cap of eukaryotic mRNA in its highest methylation state contains four methyl groups (red). The $N^{7}$-methylguanosine $\left(\mathrm{m}^{7} \mathrm{G}\right), N^{6}, 2^{\prime}$-O-dimethyl $\left(\mathrm{m}^{6} \mathrm{Am}\right)$, and $2^{\prime}-\mathrm{O}$-methyl $\left(\mathrm{N}_{\mathrm{m}}\right)$ moieties are indicated. Note that the $\mathrm{m}^{6} \mathrm{Am}$ at the first position can also be a 2-Omethylated nucleotide $\left(A_{m}, G_{m}, C_{m}, U_{m}\right)$, whereas unmodified nucleotides are rare at this position. At the second position, although $\mathrm{N}_{\mathrm{m}}$ is depicted here, unmodified nucleotides are also frequently present.

$\mathrm{N}_{\mathrm{m}}$ may also be present internally in mammalian and yeast mRNA (Dai et al. 2017; Bartoli et al. 2018).

The next modified nucleotide to be identified was a dimethylated nucleotide, $\mathrm{m}^{6} \mathrm{Am}$. When analyzing the $2^{\prime}$ $O$-methylated cap nucleotides, Wei and colleagues noticed a base-methylated version of Am and shortly after were able to confirm that the additional methylation occurred at the $N^{6}$ position of this nucleotide (Wei et al. 1975a, 1975b).

The eighth and ninth methylated nucleotides discovered in mRNA are $\mathrm{m}^{5} \mathrm{C}$ and $\mathrm{m}^{1} \mathrm{~A}$, respectively. One study that used $\left[{ }^{3} \mathrm{H}\right.$-methyl]-methionine labeling showed evidence for $\mathrm{m}^{5} \mathrm{C}$ in mRNA in the 1970s (Dubin and Taylor 
1975), with the first transcriptome-wide $\mathrm{m}^{5} \mathrm{C}$ mapping study in 2012 (Squires et al. 2012). In contrast, evidence for $\mathrm{m}^{1} \mathrm{~A}$ in mRNA came only recently (Dominissini et al. 2016; $\mathrm{Li}$ et al. 2016). Both $\mathrm{m}^{5} \mathrm{C}$ and $\mathrm{m}^{1} \mathrm{~A}$ were initially described as highly abundant (Squires et al. 2012; Dominissini et al. 2016), but other researchers have argued that mass spectrometry-based detection of these modifications in poly(A) RNA reflects contamination from ribosomal RNA (rRNA) and transfer RNA (tRNA) (Legrand et al. 2017), and it has been argued that problems in the mapping approaches have overestimated the prevalence by $\sim 1000-$ fold (Safra et al. 2017). Nevertheless, it appears likely that these modifications are present in rare and select mRNAs (Safra et al. 2017) but may not represent a general epitranscriptomic mechanism as originally proposed.

It should be noted that not all modified nucleotides in mRNA are methylated. Inosine is the product of RNA editing, and pseudouridine, an abundant modification in rRNA and tRNA, was recently shown to be present in mammalian and yeast mRNA (Carlile et al. 2014; Lovejoy et al. 2014; Schwartz et al. 2014). 5-hydoxymethyl cytosine is an oxidized product of $\mathrm{m}^{5} \mathrm{C}$ and was originally mapped in Drosophila mRNA (Delatte et al. 2016). 5hydoxymethyl cytosine has recently been proposed to be present also in mammalian mRNA (Shen et al. 2018). 8oxo-G has also been detected in mRNA, and is largely thought to represent a product of oxidative damage (Shan et al. 2003).

\section{ADVANTAGES AND CHALLENGES OF BIOCHEMICAL METHODS}

Traditionally, modified mRNA nucleotides were identified by purifying poly(A) RNA, followed by the detection of modified nucleotides by classical biochemical methods like chromatography. This approach does not definitively establish that the modified nucleotide is in mRNA, largely because poly(A) RNA can have low levels of rRNA and tRNA contamination and can contain poly(A)-containing transcripts that are not mRNA. As a result, transcriptomewide mapping has become the major method for detecting nucleotide modifications in mRNA. This approach can reveal the precise mRNAs that contain the modified nucleotide and the location of the modified nucleotide within the transcript.

Nevertheless, biochemical methods are useful and have revealed key principles of $\mathrm{m}^{6} \mathrm{~A}$ biology. The advantage of chromatography is that it is inherently quantitative because the levels of the modified and nonmodified nucleotides can usually be measured in parallel. This allows the fractional abundance of the modified nucleotide to be readily determined.
In addition, the quantitative readout of the purification/ detection strategy allows relatively straightforward kinetic studies of the modification dynamics. For example, it was shown that $\mathrm{m}^{6} \mathrm{~A}$ methylation is rapidly lost from polyadenylated mRNA in the cytosol, suggesting a fast turnover of $\mathrm{m}^{6} \mathrm{~A}$-containing mRNA (Friderici et al. 1976; Sommer et al. 1978).

The power of these chromatographic methods is also underscored by the use of clever purification and digestion strategies that revealed which parts of the mRNA are modified. When polyadenylated mRNA was partially hydrolyzed and repurified using poly(A) selection, it was found that $\mathrm{m}^{6} \mathrm{~A}$ is enriched in the $3^{\prime}$ portion of transcripts (Perry et al. 1975; Beemon and Keith 1977), a finding that was validated by more recent transcriptome-wide $\mathrm{m}^{6} \mathrm{~A}$ maps (Dominissini et al. 2012; Meyer et al. 2012; Linder et al. 2015). Also, systematic digestion of the modified mRNAs with nucleases with different nucleotide specificities revealed that $\mathrm{m}^{6} \mathrm{~A}$ occurs in a consensus motif which best described as $\mathrm{N}_{1}-\mathrm{R}-\mathrm{A}-\mathrm{C}-\mathrm{N}_{2}$, with $\mathrm{R}$ being a purine, $\mathrm{N}_{1}$ being mostly a purine and $\mathrm{N}_{2}$ being rarely a $\mathrm{G}$ (Wei et al. 1976; Schibler et al. 1977).

The high sensitivity of the radioactive readout also allowed the detection of modifications that are less abundant than $m^{6} A$. For example, $m^{5} \mathrm{C}$ was detected in mRNA that underwent two rounds of poly(A)-enrichment at levels of $\sim 0.18 \mathrm{~m}^{5} \mathrm{C}$ residues/1000 nt (Dubin and Taylor 1975). However, these investigators noted that others did not detect $\mathrm{m}^{5} \mathrm{C}$ in mRNA and it was possible that it originated from a contaminating non-mRNA species (Dubin and Taylor 1975).

Indeed, contaminating tRNA or rRNA can lead to spurious detection of modified nucleotides or an overestimation of the modified nucleotide in mRNA. This reflects the high abundance of modified nucleotides in tRNA and rRNA. Even a small amount of these contaminating species can lead to the erroneous conclusion that a modified nucleotide is present in mRNA. In line with this, sequencing of poly(A) RNA subjected to two rounds of purification using oligo-dT beads showed that $\sim 40 \%$ of the RNA can be rRNA (Legrand et al. 2017), consistent with other studies showing that poly(A) RNA preparations contain diverse noncoding RNAs including rRNA (Cui et al. 2010; Sultan et al. 2014; Zhao et al. 2014). Thus, any measurement of modified nucleotides in poly(A) RNA may reflect the presence of the modified nucleotide in these ubiquitous contaminants.

It should be noted, however, that contaminating RNA can also give an impression of reduced $\mathrm{m}^{6} \mathrm{~A}$ levels. Because $18 \mathrm{~S}$ and $28 \mathrm{~S}$ rRNA contain approximately 420 and approximately 850 unmodified adenosines, respectively, their average $\mathrm{m}^{6} \mathrm{~A} / \mathrm{A}$ ratio is 2 per 1270 or $0.16 \%$, which is below the $0.5 \% \mathrm{~m}^{6} \mathrm{~A} / \mathrm{A}$ ratio of mRNA (Sommer et al. 1978). 
Accordingly, if the ratio of $\mathrm{m}^{6} \mathrm{~A} / \mathrm{A}$ is measured, contamination of a human mRNA sample with rRNA leads to an underestimation of its $\mathrm{m}^{6} \mathrm{~A} / \mathrm{A}$ ratio.

The problem of contaminating tRNA or rRNA is similarly a problem for more recent techniques such as mass spectrometry and ELISA-based detection methods.

To overcome the problem of contaminants, Fray and colleagues developed an approach that allows $\mathrm{m}^{6} \mathrm{~A}$ in the mRNA to be selectively detected, even in the presence of contaminating rRNA and small nuclear RNA (snRNA) (Zhong et al. 2008). In this approach, RNA is treated with ribonuclease $\mathrm{T} 1$, resulting in cleavage of RNA after $\mathrm{G}$ residues. The resulting RNA fragments are radiolabeled at their $5^{\prime}$ ends. After RNA hydrolysis the labeled nucleotides are detected by thin-layer chromatography. Because $\mathrm{m}^{6} \mathrm{~A}$ in snRNA and rRNA exist in a C-m ${ }^{6} \mathrm{~A}-\mathrm{G}$ context (Shimba et al. 1995) and A-m ${ }^{6} \mathrm{~A}-\mathrm{C}$ context (Boccaletto et al. 2018), respectively, these $\mathrm{m}^{6} \mathrm{~A}$ residues are not at a $5^{\prime}$ end after ribonuclease $\mathrm{T} 1$ treatment and therefore these $\mathrm{m}^{6} \mathrm{~A}$ residues are not radiolabeled. In contrast, $\mathrm{m}^{6} \mathrm{~A}$ in mRNA is predominantly found in a G-m ${ }^{6} \mathrm{~A}-\mathrm{C}$ context (Schibler et al. 1977), and therefore is selectively measured.

Nevertheless, the concern about contamination makes it essential to determine if the source of a modified nucleotide is mRNA or a contaminant species. For this reason, transcriptome-wide mapping has become the method of choice for studying RNA modifications in mRNA.

\section{NEXT-GENERATION SEQUENCING-BASED TECHNOLOGIES FOR MAPPING INTERNAL NUCLEOTIDE MODIFICATIONS}

\section{$4.1 \mathrm{~m}^{6} \mathrm{~A}$}

\subsubsection{Mapping $m^{6}$ A Using Antibody-Based Enrichment}

The original maps of $\mathrm{m}^{6} \mathrm{~A}$ were generated by using $\mathrm{m}^{6} \mathrm{~A}-$ specific antibodies to immunoprecipitate $\mathrm{m}^{6} \mathrm{~A}$-containing RNA fragments from poly(A) RNA fractions (Fig. 2A) (Dominissini et al. 2012; Meyer et al. 2012). The antibody-bound RNA fragments were then subjected to RNA sequencing (RNA-seq). This technique, called MeRIP-seq (methylated RNA immunoprecipitation and sequencing) (Meyer et al. 2012) or $\mathrm{m}^{6} \mathrm{~A}$-seq (Dominissini et al. 2012), has been extended to other modified nucleotide-specific antibodies to map $\mathrm{hm}^{5} \mathrm{C}$ in Drosophila (Delatte et al. 2016), $\mathrm{m}^{1} \mathrm{~A}$ in mammals (Dominissini et al. 2016; Li et al. 2016), and $\mathrm{m}^{5} \mathrm{C}$ in yeast and bacteria (Edelheit et al. 2013).

In the $\mathrm{m}^{6} \mathrm{~A}$-mapping studies, $\mathrm{m}^{6} \mathrm{~A}$ sites throughout the transcriptome were predicted based on the presence of multiple overlapping aligned sequencing reads, or "peaks" (Fig. 3A). To call peaks, computational strategies are used to identify transcriptomic locations where the read accumulations are enriched in the immunoprecipitated sample, but not the input sample. Together, these strategies have identified $13,471 \mathrm{~m}^{6} \mathrm{~A}$ peaks in HEK 293T cells (Meyer et al. 2012) and 12,769 $\mathrm{m}^{6} \mathrm{~A}$ peaks in HepG2 cells (Dominissini et al. 2012).

\subsubsection{Detecting $m^{6} A$ at Single-Nucleotide Resolution by Covalent Cross-Linking to Antibodies}

One of the key challenges with distinguishing $\mathrm{m}^{6} \mathrm{~A}$ from $\mathrm{A}$ is that there is no chemical reagent that selectively reacts with $\mathrm{m}^{6} \mathrm{~A}$ or $\mathrm{A}$. This contrasts with $\mathrm{m}^{5} \mathrm{C}$ and pseudouridine (see below), which each benefit from chemoselective reactions that enabled the development of chemical-based mapping approaches that map the modified nucleotides at single-nucleotide resolution.

To achieve chemoselective detection of $\mathrm{m}^{6} \mathrm{~A}$, we developed miCLIP ( $\mathrm{m}^{6} \mathrm{~A}$ individual nucleotide cross-linking and immunoprecipitation). miCLIP exploits the ability of $\mathrm{m}^{6} \mathrm{~A}$ antibodies to selectively bind $\mathrm{m}^{6} \mathrm{~A}$ (Linder et al. 2015). To generate a chemical modification at $\mathrm{m}^{6} \mathrm{~A}$ sites, ultraviolet (UV) light is used to create a covalent bond between RNA and a bound $\mathrm{m}^{6} \mathrm{~A}$-specific antibody (Fig. 2A). After proteolysis, reverse transcription and high-throughput sequencing, cross-link-induced single-nucleotide substitutions, and cDNA truncations are characterized and used to call potential $\mathrm{m}^{6} \mathrm{~A}$ sites throughout the transcriptome (Fig. 3B,C). This provided the first single-nucleotide maps of $\mathrm{m}^{6} \mathrm{~A}$ (Linder et al. 2015).

Importantly, not all $\mathrm{m}^{6} \mathrm{~A}$-binding antibodies are suitable for miCLIP. Characterization of multiple $\mathrm{m}^{6} \mathrm{~A}$ antibodies showed that only one antibody resulted in efficient termination of reverse transcription at $\mathrm{m}^{6} \mathrm{~A}$, whereas another caused nucleotide misincorporations at the +1 position relative to the $\mathrm{m}^{6} \mathrm{~A}$ (Linder et al. 2015). Other $\mathrm{m}^{6} \mathrm{~A}$ binding antibodies did not produce $\mathrm{m}^{6} \mathrm{~A}$ mutations that were efficient or located at a consistent position relative to diverse $\mathrm{m}^{6} \mathrm{~A}$ sites.

It is difficult to distinguish cross-link-induced misincorporations from sequencing errors, so statistical modeling is often applied (Zhang and Darnell 2011; Weyn-Vanhentenryck et al. 2014). However, prior knowledge about $\mathrm{m}^{6} \mathrm{~A}$ helped to validate the specificity of miCLIP. First, $\mathrm{m}^{6} \mathrm{~A}$ is known to occur in a specific consensus motif, so most sites called by miCLIP outside of this motif are likely to be false positives. Second, a number of methylatable sites had been tested for their methylation status (and stoichiometry) by thin layer chromatography (Liu et al. 2013). These features allowed us to establish criteria for calling of $\mathrm{m}^{6} \mathrm{~A}$ sites from cross-link-induced mutations that identified 11,832 sites with an estimate of $\sim 12 \%$ false positives (Linder et al. 2015). 
B. Linder and S.R. Jaffrey

A

A

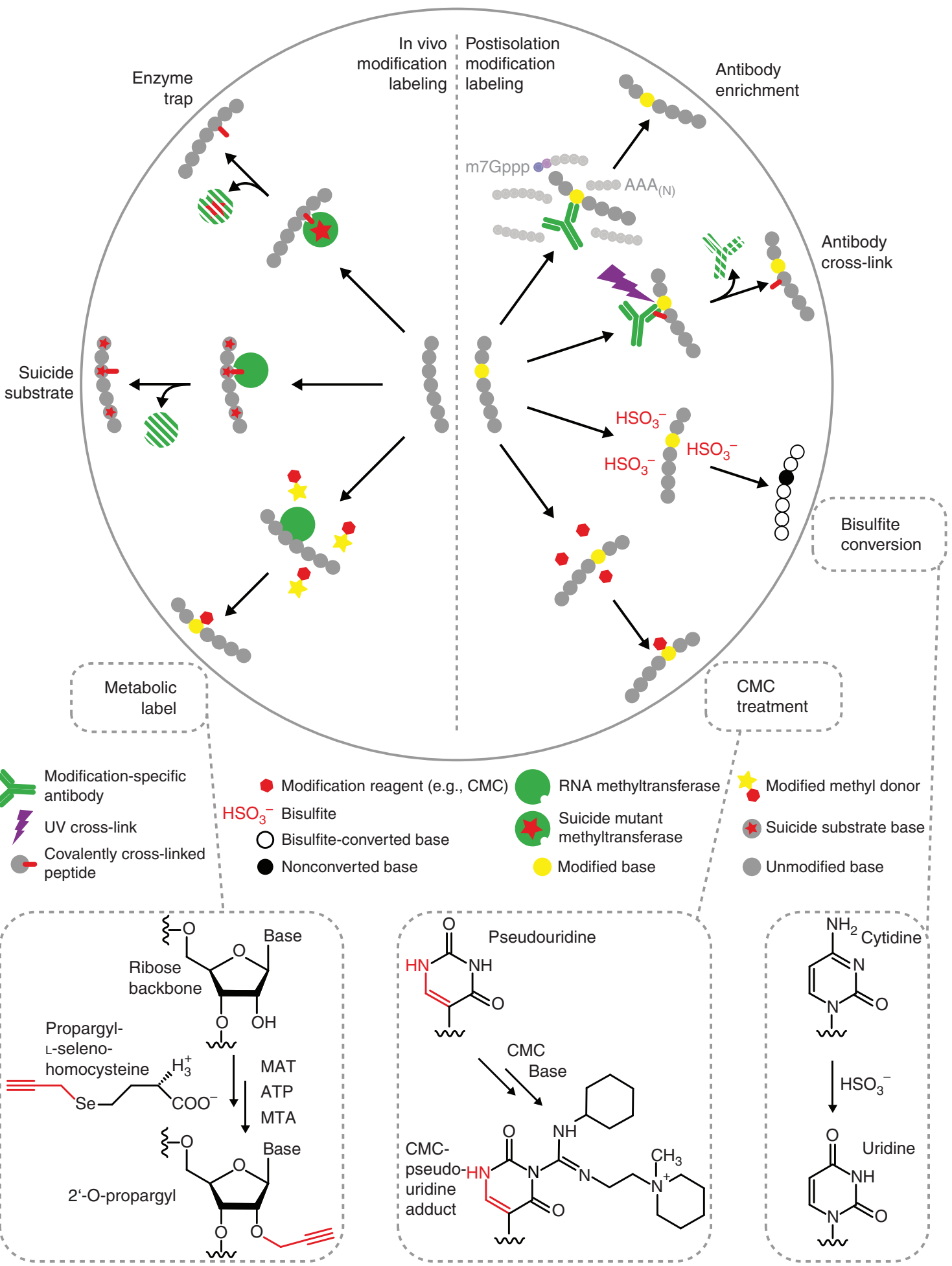

Figure 2. Approaches for the labeling and detection of modified nucleotides. (A) As many modified nucleotides are refractory to detection by classical molecular biology techniques, a variety of approaches have been developed that facilitate their discovery (see main text for details and references). Strategies to label modified nucleotides in vivo (left). A mutant methyltransferase can be introduced into cells that traps a covalent reaction intermediate. After proteolysis, a covalently attached peptide remnant marks the substrate nucleotide (upper left). A similar remnant peptide can be obtained if a nucleotide analog is incorporated into RNA that serves as a suicide substrate for the methyltransferase (middle left). (Legend continues on following page.) 
A
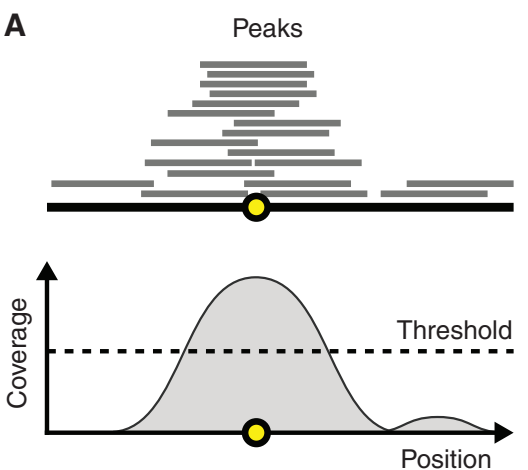

B
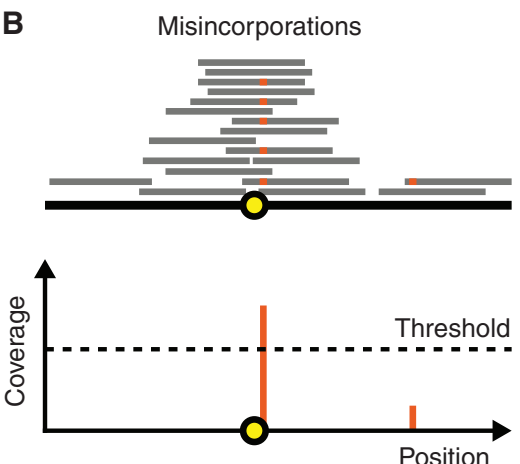

C
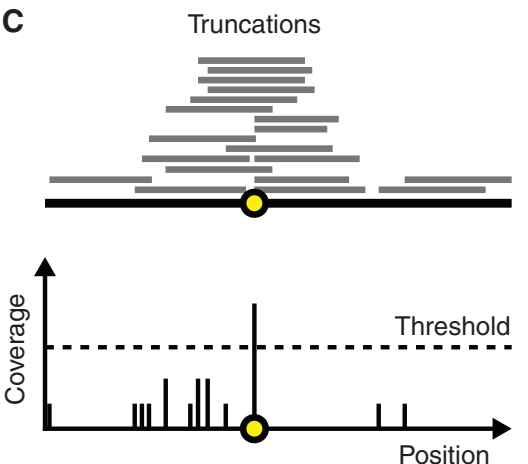

Figure 3. Strategies to identify modifications in high-throughput sequencing data. After enrichment and/or labeling, modified RNAs are subjected to reverse transcription, library preparation, and sequencing. Sequenced reads (horizontal gray lines) are then mapped to a reference genome or transcriptome (horizontal black line). (A) A peak calling approach is often used in antibody-based enrichment experiments. It tries to identify regions in the transcriptome where more reads are captured than expected from background noise. Although the shape of the peak and the observed midpoint can sometimes be used to infer the position of the methylated nucleotide (yellow circle), the resolution of this approach is limited. $(B)$ Modifications or chemical treatments that alter the base-pairing properties of a nucleotide often lead to nucleotide misincorporations during reverse transcription. After mapping, these mutations are identified as mismatches to the reference sequence (orange squares). By counting these mismatches and comparing them to the mismatch distribution expected by background noise (e.g., from sequencing errors), modified nucleotides can be identified with single-nucleotide resolution. $(C)$ Some modifications cause the reverse transcriptase to abort cDNA synthesis. The resulting accumulation of read $5^{\prime}$ ends can be compared with the background distribution to identify sites with significant enrichment of such truncations. Although these truncations in principle also mark modification sites with base resolution, this method is more prone to false positives because the background noise is typically higher than what is observed for misincorporations.

\subsection{Pseudouridine}

Pseudouridine is a highly abundant nucleotide modification in ribosomal RNA and is also present in tRNA (Modomics database; Boccaletto et al. 2018). A series of studies in 2014 showed that pseudouridines are also found at specific locations in mammalian and yeast mRNA (Carlile et al. 2014; Lovejoy et al. 2014; Schwartz et al. 2014).

Pseudouridine is an enzymatically isomerized version of uridine in which the uracil is detached from the ribose, undergoes a rotation, and then is reattached to the ribose. Despite this isomerization, pseudouridine behaves like uri-

Figure 2. (Continued) Reactive analogs of methyl-group donors can be used to metabolically label target nucleotides (lower left). This approach is promising because methyl-donor analogs have been developed that make use of versatile propargyl groups that can be further reacted using click chemistry. Also, metabolic labeling in principle could be used to study methylation kinetics on a transcriptome-wide scale. Many techniques use chemical strategies to "hypermodify" RNAs after they are isolated from cells (right). Modification-specific antibodies are used to enrich modified RNA fragments (top right). By using ultraviolet (UV) light to cross-link them to the bound RNA, modificationspecific antibodies can also be used as chemical agents to mark modified nucleotides (or their close vicinity; upper right). Treatment of RNA with bisulfite leads to the conversion of cytidine to uridine (lower right). This deamination is far less efficient for $\mathrm{m}^{5} \mathrm{C}$, and such nonconversion events can be used as a signal to detect $\mathrm{m}^{5} \mathrm{C}$. Pseudouridine can be converted to a bulky nucleotide species using $N$-cyclohexyl- $N^{\prime}$-(2-morpholinoethyl)carbodiimide (CMC; bottom right). Uridine also reacts with CMC but is eliminated from this unmodified nucleotide by treatment with base. (B) Chemical reactions used to label modified nucleotides. (Left panel) The methionine analog propargyl-L-selenohomocysteine can be used to label positions of methyl groups. Propargyl-L-seleno-homocysteine is readily taken up by cells and converted into a $S$-adenosyl-methionine analog by cellular methionine adenosyltransferases (MAT). The bioorthogonal propargyl group is then transferred to the $2^{\prime}$-hydroxyl position of nucleotides in ribosomal RNA (rRNA) in cells. In in vitro reactions, the N6 position of adenosine can also be modified by an N6-adenosine methyltransferase (MTA). In both cases, the propargyl-modified nucleotide can be biotinylated by click chemistry for selective recovery of RNA that contains the modified nucleotide. (Middle panel) Labeling of pseudouridine with CMC ( $N$-cyclohexyl- $N^{\prime}$ - $(\beta$ - $[N$-methylmorpholino] ethyl)carbodiimide). Note that CMC reacts with other nucleotides as well but is eliminated from the other nucleotides with treatment by base. (Right panel) Deamination of cytidine by bisulfite $\left(\mathrm{HSO}_{3}{ }^{-}\right)$to yield uridine. Because of the methylation at the N5 position, this reaction is inefficient for $\mathrm{m}^{5} \mathrm{C}$. 
dine during reverse transcription. As a result, it does not produce a reverse transcription signature that lends itself to straightforward detection by sequencing (Ryvkin et al. 2013).

To make pseudouridine detectable, the most common method is to use $N$-cyclohexyl- $N^{\prime}$-( $\beta$ - $[N$-methylmorpholino]ethyl)carbodiimide (CMC) (Fig. 2B, middle panel). $\mathrm{CMC}$ reacts to form an adduct with $\mathrm{U}$, pseudouridine, and to a lesser extent G (Ho and Gilham 1971). However, the CMC adduct is readily reversible by alkali treatment for $\mathrm{U}$ and $\mathrm{G}$. In contrast, the CMC adduct on pseudouridine is unaffected, leaving a bulky CMC moiety that induces reverse transcription stops, which can be detected by next-generation sequencing.

$\Psi$-seq, Pseudo-seq (pseudouridine sequencing), and PSI-seq (pseudouridine site identification sequencing) used this approach to map pseudouridines throughout the transcriptome in yeast and mammals (Carlile et al. 2014; Lovejoy et al. 2014; Schwartz et al. 2014). Pseudouridine sites were called based on recurrent reverse transcription terminations, resulting in approximately 50 to 300 mapped sites in yeast and 100 to 400 mapped sites in human cell lines (Carlile et al. 2014; Lovejoy et al. 2014; Schwartz et al. 2014). Together, these studies led to single-nucleotide resolution maps of pseudouridine in yeast and mammals.

Pseudouridine in mRNA was typically found to exist in sequence motifs that resembled the motifs in tRNA that are modified with pseudouridine. In some cases, pseudouridine was found in motifs consistent with snoRNA-mediated pseudouridine formation by the dyskerin enzyme; however, these were $<25 \%$ of all sites (Schwartz et al. 2014). Importantly, the investigators validated sites by mapping pseudouridine in yeast lacking specific pseudouridine-forming enzymes, thereby providing independent proof that a significant fraction of mapped sites indeed represent pseudouridine (Carlile et al. 2014; Schwartz et al. 2014).

A more sensitive version of this method was described in which CMC was replaced with a clickable analog of CMC (Li et al. 2015). In this method, an alkyne-modified form of CMC is reacted with RNA. After the CMC-moiety is removed from $U$ and $G$, the remaining adducts are biotinylated using click chemistry, and the RNA is recovered for sequencing. This approach, which allows greater sequencing depth because only pseudouridine-containing RNA is recovered, is particularly valuable because it allows pseudouridine residues in low abundance mRNAs to be detected (Li et al. 2015).

The function of pseudouridine remains elusive. Pseudouridine does not impair protein synthesis by the ribosome, as shown by the translation of transfected pseudouridine-containing reporter mRNAs into functional en- zymes (Karikó et al. 2008). Pseudouridine is known to promote the stability of helices by increasing the stability of base-stacking interactions (Davis 1995). Therefore, it is conceivable that the function of pseudouridine is to stabilize specific double-stranded RNA structures.

\section{$4.3 \mathrm{~m}^{5} \mathrm{C}$}

\subsubsection{Bisulfite Mapping of $m^{5} \mathrm{C}$ in $m R N A$}

Methylated cytosine is most widely known as a modified nucleobase in DNA, forming the $\mathrm{m}^{5} \mathrm{dC}$ nucleotide (5-methyl deoxycytidine). This modification is usually referred to by the name of the modified base (i.e., 5-methylcytosine $[5 \mathrm{mC}])$ rather than by the name of the nucleotide $\left(\mathrm{m}^{5} \mathrm{dC}\right)$. However, $5 \mathrm{mC}$ is also a constituent of $\mathrm{m}^{5} \mathrm{C}$, an RNA nucleotide that is found in rRNA and tRNA (Modomics database; Boccaletto et al. 2018).

$5 \mathrm{mC}$ in DNA can be detected based on its selective resistance to modification by bisulfite (Fig. 2B, right panel) (Frommer et al. 1992). Bisulfite treatment leads to deamination of unmodified $\mathrm{C}$, but does not efficiently deaminate $5 \mathrm{mC}$. Thus, after bisulfite treatment and the subsequent deamination step, cytosines are sequenced as thymidines. Because $5 \mathrm{mC}$ residues are not deaminated, they are read as cytosines during DNA sequencing.

The bisulfite-based $5 \mathrm{mC}$ detection approach for DNA was applied to RNA to map $m^{5} \mathrm{C}$ in diverse types of RNA species (Schaefer et al. 2009). Most notably, this method was recently applied to poly(A) RNA to map $\mathrm{m}^{5} \mathrm{C}$ in mRNA. Based on global mapping of bisulfite-resistant cytidine residues, $10,275 \mathrm{~m}^{5} \mathrm{C}$ sites were mapped at single-nucleotide resolution in HeLa cell mRNA and long-noncoding RNA (lncRNA) (Squires et al. 2012).

The high abundance of $\mathrm{m}^{5} \mathrm{C}$ in mRNA has been questioned (Legrand et al. 2017). The primary concern is that the bisulfite mapping approach can be associated with some cytidine residues showing lack of bisulfite-mediated deamination, but not actually being methylated (Legrand et al. 2017). Why might this occur? The most likely reason is that some cytidines may be inaccessible to bisulfite because they are located within a structured region of RNA. Another reason is that the bisulfite modification step and deamination steps may not be performed to completion. Unlike DNA, which is fairly stable, RNA is susceptible to degradation by hydrolysis. Therefore, milder conditions are used with RNA, which can lead to incomplete cytidine deamination and thus the appearance of unconverted cytidines at non- $\mathrm{m}^{5} \mathrm{C}$ positions (Schaefer et al. 2009). Lastly, read mapping can be difficult because bisulfite-converted RNA reads are typically short (to facilitate narrow peaks) and of low complexity (because most cytidines are converted to 
thymidine). Therefore, unambiguous alignment of these reads to the genome is difficult to achieve, which could alter the measurements of the bisulfite-mediated conversion rates (Legrand et al. 2017).

Lyko and colleagues have argued that the appearance of unmodified cytidines does not reflect $\mathrm{m}^{5} \mathrm{C}$, but instead reflects the statistical variation in bisulfite modification that would normally occur in RNA (Legrand et al. 2017). In earlier studies, a threshold cutoff was used to call $\mathrm{m}^{5} \mathrm{C}$ sites based on whether the residue showed a reduction in the conversion rate. Lyko and colleagues argued that the use of a cutoff can be misleading because the conversion rate should be modeled as a statistical distribution. As with any distribution, there will be tails reflecting cytosines with increased or decreased conversion rates. Lyko and colleagues calculated that the number of cytidines that showed reduced conversions in $\mathrm{m}^{5} \mathrm{C}$ mapping experiments was not significantly larger than what would be expected based on a statistical distribution of random nonconversions. Because these various questions that have been raised concerning $\mathrm{m}^{5} \mathrm{C}$ mapping, it will be important to biochemically validate previously predicted $\mathrm{m}^{5} \mathrm{C}$ sites (Squires et al. 2012; Amort et al. 2013). Biochemical validation can be used to assess the false-positive rates in $\mathrm{m}^{5} \mathrm{C}$ mapping studies and would therefore enable the true abundance of $\mathrm{m}^{5} \mathrm{C}$ in mRNA to be extrapolated.

\subsubsection{Enzyme-Trapping Methods to Map $m^{5} \mathrm{C}$}

In addition to bisulfite mapping, another method to map $\mathrm{m}^{5} \mathrm{C}$ takes advantage of the relatively unique enzymatic mechanism of cytosine methyltransferases. Cytosine methyltransferases form a covalent adduct with cytosine as an initial step before methylation (Liu and Santi 2000). Two approaches have been described to trap this intermediate and thereby identify the RNAs and their cytosines that are targets of cytosine methyltransferases (Fig. 2A) (Hussain et al. 2013; Khoddami and Cairns 2013).

In Aza-IP (5-azacytidine-mediated RNA immunoprecipitation), a modified cytosine is used to trap cytosine methyltransferases (Khoddami and Cairns 2013). In this method, cells are cultured with 5-azacytidine (5-azaC) in the culture media. This nucleotide is incorporated as if it were cytidine during RNA transcription. When cytosine methyltransferases attempt to methylate 5 -azaC, they remain covalently bound to 5 -azaC, resulting in a covalent enzyme-RNA intermediate that cannot be resolved. In the Aza-IP study, the cytosine methyltransferases DNMT2 or NSUN2 were immunoprecipitated to detect covalently bound RNA. Hydrolysis by divalent metal ions was used to release the bound RNA, resulting in opening of the 5 -azaC ring that could be detected by the presence of nu- cleotide misincorporations seen during sequencing of the cDNA (Khoddami and Cairns 2013). The misincorporations also allow high-resolution mapping of the cytosines targeted by these enzymes.

In a related approach, no modified nucleotide was used. Instead, an NSun2 mutant that cannot resolve the covalent enzyme-RNA intermediate was expressed in cells (Hussain et al. 2013). This approach, termed miCLIP (methylation iCLIP; different from $\mathrm{m}^{6} \mathrm{~A}$ miCLIP above), involves immunoprecipitating the NSun2-RNA complexes and sequencing bound RNAs. Peptide remnants of the covalently bound enzyme cause termination of reverse transcription. These terminations are then used for the high-resolution mapping of $\mathrm{m}^{5} \mathrm{C}$ in RNA (Hussain et al. 2013).

In both approaches, $\mathrm{m}^{5} \mathrm{C}$ was detected in tRNA and other noncoding RNAs. However, $\mathrm{m}^{5} \mathrm{C}$ was not readily detected in mRNA, in contrast to $\mathrm{m}^{5} \mathrm{C}$ mapping with bisulfite. $\mathrm{m}^{5} \mathrm{C}$ miCLIP detected $312 \mathrm{~m}^{5} \mathrm{C}$ sites in mRNA (Hussain et al. 2013), while just one high-confidence $\mathrm{m}^{5} \mathrm{C}$ in mRNA was detected with Aza-IP (Khoddami and Cairns 2013). The ability of these methods to detect $\mathrm{m}^{5} \mathrm{C}$ in mRNA may however have been limited, because the enzyme-trapping method did not enrich for mRNA, which is much lower in abundance than tRNA or rRNA. Thus, these studies do not exclude the possibility that $\mathrm{m}^{5} \mathrm{C}$ is prevalent in mRNA.

\section{$4.4 \mathrm{~m}^{1} \mathrm{~A}$}

\subsubsection{Antibody-Enrichment-Based Mapping of $m^{1} A$}

Two antibody-based $\mathrm{m}^{1} \mathrm{~A}$ mapping approaches, $\mathrm{m}^{1} \mathrm{~A}$-seq $\left(\mathrm{m}^{1} \mathrm{~A}\right.$ methylated RNA immunoprecipitation and sequencing) and $\mathrm{m}^{1} \mathrm{~A}$-ID-seq $\left(\mathrm{m}^{1} \mathrm{~A}\right.$-specific RNA immunoprecipitation with demethylase-assisted RNA sequencing), provided evidence that $\mathrm{m}^{1} \mathrm{~A}$, a modified nucleotide previously known to occur in tRNA and rRNA (Modomics database; Boccaletto et al. 2018) is also present in mRNA (Dominissini et al. 2016; Li et al. 2016).

These two initial studies were similar to the original $\mathrm{m}^{6} \mathrm{~A}$ mapping approach in that they relied on mRNA fragment pulldown using a modification-specific antibody (Dominissini et al. 2016; Li et al. 2016). In addition, they took advantage of unique features of $\mathrm{m}^{1} \mathrm{~A}$. As $\mathrm{m}^{1} \mathrm{~A}$ is unable to form a Watson-Crick base pair with thymidine, this nucleotide blocks reverse transcription. Therefore, both of the initial transcriptome-wide maps of $\mathrm{m}^{1} \mathrm{~A}$ used the tendency of $\mathrm{m}^{1} \mathrm{~A}$ to introduce reverse transcription stops to help distinguish between nonspecific peaks and peaks that were indeed caused by $\mathrm{m}^{1} \mathrm{~A} . \mathrm{m}^{1} \mathrm{~A}$ peaks were enriched in "trough"-like peaks $\left(\mathrm{m}^{1} \mathrm{~A}\right.$-seq) or show a drop in sequencing coverage upstream of the $\mathrm{m}^{1} \mathrm{~A}\left(\mathrm{~m}^{1} \mathrm{~A}-\mathrm{ID}\right.$-seq). Furthermore, the RNA was either treated with the $\mathrm{m}^{1} \mathrm{~A}$ 
demethylase AlkB ( $\mathrm{m}^{1} \mathrm{~A}$-ID-seq) or subjected to Dimroth rearrangement $\left(\mathrm{m}^{1} \mathrm{~A}\right.$-seq) to convert $\mathrm{m}^{1} \mathrm{~A}$ into $\mathrm{m}^{6} \mathrm{~A}$, which does not induce reverse transcription stops. These studies identified more than $7000 \mathrm{~m}^{1} \mathrm{~A}$ peaks in $4000 \mathrm{mRNAs}$ and estimated an average stoichiometry of $20 \%$, sometimes exceeding 50\% (Dominissini et al. 2016). Based on the localization of $\mathrm{m}^{1} \mathrm{~A}$ near start codons and bioinformatic analysis of published ribosome profiling data, $\mathrm{m}^{1} \mathrm{~A}$ was proposed to enhance mRNA translation efficiency (Dominissini et al. 2016). These studies suggested that $\mathrm{m}^{1} \mathrm{~A}$ is a previously unrecognized, yet highly prevalent internal base modification in mRNA that regulates mRNA translation.

Two subsequent mapping studies reported that $\mathrm{m}^{1} \mathrm{~A}$ is present at fewer sites and in different transcripts than initially reported. These studies sought to map the exact sites of $\mathrm{m}^{1} \mathrm{~A}$ in the antibody-immunoprecipitated RNA (Li et al. 2017; Safra et al. 2017), and took advantage of the ability of $\mathrm{m}^{1} \mathrm{~A}$ to induce nucleotide misincorporations during reverse transcription (Hauenschild et al. 2015). This effect can be amplified by using specific polymerases such as the thermostable group II intron reverse transcriptase (TGIRT), which has an increased frequency of misincorporation when encountering $\mathrm{m}^{1} \mathrm{~A}$ (Safra et al. 2017). Thus, TGIRT was used to analyze RNA immunoprecipitated with the $\mathrm{m}^{1} \mathrm{~A}$ antibody to determine if and where $\mathrm{m}^{1} \mathrm{~A}$-induced misincorporations were present in the recovered cDNA (Li et al. 2017; Safra et al. 2017) Therefore, rather than relying on $\mathrm{m}^{1} \mathrm{~A}$ peaks, this approach added specificity by searching for $\mathrm{m}^{1} \mathrm{~A}$-induced misincorporations.

Intriguingly, this high-resolution approach showed that most mRNA fragments immunoprecipitated with the $\mathrm{m}^{1} \mathrm{~A}$ antibody lacked $\mathrm{m}^{1} \mathrm{~A}$-induced misincorporations. In fact, only seven cytosolic mRNAs contained misincorporations consistent with the presence of $\mathrm{m}^{1} \mathrm{~A}$ (Safra et al. 2017). Surprisingly, the investigators identified five $\mathrm{m}^{1} \mathrm{~A}$-containing mitochondrial mRNAs (Safra et al. 2017). For most of these 13 mRNAs, the stoichiometry of $\mathrm{m}^{1} \mathrm{~A}$ was very low. Indeed, the stoichiometry was so low that many cells are unlikely to contain even a single copy of a $\mathrm{m}^{1} \mathrm{~A}$-modified mRNA. None of the mapped sites were localized near start codons. Thus, the use of TGIRT in $\mathrm{m}^{1} \mathrm{~A}$-seq revealed that $\mathrm{m}^{1} \mathrm{~A}$ is approximately 1000 -fold less prevalent and in most cases much lower in stoichiometry than originally described (Safra et al. 2017).

Only one mRNA showed a high stoichiometry $\mathrm{m}^{1} \mathrm{~A}$, the mitochondrial mRNA that encodes the enzyme NADH dehydrogenase-5 (ND5). The investigators asked whether the stoichiometry of this modification changes in different cellular states, which might suggest that this modification has a regulatory function, at least in ND5. The authors found that $\mathrm{m}^{1} \mathrm{~A}$ modification was high in stoichiometry in egg cells and up to the four-cell stage but dropped in the late blastocyst stage (Safra et al. 2017). Thus, $\mathrm{m}^{1} \mathrm{~A}$ may have a regulatory effect on ND5. The data were most consistent with an inhibitory effect on translation, consistent with the general idea that $\mathrm{m}^{1} \mathrm{~A}$ would interfere with translation, rather than enhance translation (Grozhik and Jaffrey 2018).

The finding that $\mathrm{m}^{1} \mathrm{~A}$ is a rare modified nucleotide in mRNA is consistent with the recent mass spectrometry study that found that $\mathrm{m}^{1} \mathrm{~A}$ was not detectable in highly purified poly(A) RNA (Legrand et al. 2017). These investigators were able to detect $\mathrm{m}^{1} \mathrm{~A}$ in poly(A) RNA fractions that were prepared using standard oligo-dT purification. However, they showed that these poly(A) RNA preparations contain rRNA. Notably, this poly(A) RNA purification protocol is commonly used to search for the presence of modified nucleotides in mRNA. When rigorous purification protocols were used and rRNA depletion was validated by next-generation sequencing, the investigators found that $\mathrm{m}^{1} \mathrm{~A}$ and other modified nucleotides such as $\mathrm{m}^{5} \mathrm{C}$ and $5 \mathrm{hmC}$ were depleted from the poly(A) RNA.

This study pointed out that mass spectrometry-based analysis of poly(A) RNA preparations require that the poly(A) RNA be analyzed by next-generation sequencing to rigorously quantify the presence of any rRNA or tRNA; otherwise it would not be clear if the modified nucleotide reflects low-level contamination from tRNA or if it indeed reflects the presence of an internal modified nucleotide in mRNA.

Because $\mathrm{m}^{1} \mathrm{~A}$ is especially abundant in tRNAs, it is important to determine the levels of contaminating tRNA when quantifying $\mathrm{m}^{1} \mathrm{~A}$ and other modified nucleotides in a poly(A)-enriched sample by mass spectrometry. Sequencing methods that use the TGIRT polymerase now allow the sequencing-based quantification of tRNA levels despite the high level of modified nucleotides in tRNA (Zheng et al. 2015).

Taken together, these results show that $\mathrm{m}^{1} \mathrm{~A}$ is indeed present in mRNA, but it is likely to be rare rather than highly prevalent under normal cellular conditions. Importantly, $\mathrm{m}^{1} \mathrm{~A}$ and other modifications might be of low abundance if they are transiently introduced and trigger mRNA degradation by no-go decay. Such ribosome-mediated removal of modified RNA has been found for 8-oxo-G (Simms et al. 2014). It will thus be important to determine if translational inhibition increases the abundance of $\mathrm{m}^{1} \mathrm{~A}$.

One of the important findings of the $\mathrm{m}^{1} \mathrm{~A}$ mapping studies is that the few transcripts that contain $\mathrm{m}^{1} \mathrm{~A}$ tend to contain $\mathrm{m}^{1} \mathrm{~A}$ within a structured sequence that resembles the "T-loop" of tRNA. The T-loop of tRNA contains a single $\mathrm{m}^{1} \mathrm{~A}$ in the majority of tRNA molecules in the cell. This is a form of "tRNA mimicry" that allows an mRNA to become modified by taking advantage of the structural and 
sequence specificity of tRNA-modifying enzymes (Grozhik and Jaffrey 2017). It is possible that other tRNA-modifying enzymes similarly modify mRNAs that contain structures that resemble conserved sequence or structural motifs normally found in tRNA.

Additionally, it is interesting that the more recent $\mathrm{m}^{1} \mathrm{~A}$ mapping studies focus on mitochondrial transcripts as the major target of $\mathrm{m}^{1} \mathrm{~A}$. However, unlike ND5 mRNA most of these mitochondrial transcripts are modified with exceptionally low stoichiometry. It is possible that these transcripts become methylated because of the high concentration of $\mathrm{m}^{1} \mathrm{~A}$-forming tRNA-modifying enzymes in the mitochondrial cytoplasm, which may induce spurious modification of mRNA sequences that show weak similarity to T-loops. Therefore, the functional significance of these low stoichiometry $\mathrm{m}^{1} \mathrm{~A}$ modifications may be minimal.

\subsection{2'-O-Methylated Nucleotides $\left(\mathrm{N}_{\mathrm{m}}\right)$}

2'-O-methylated nucleotides, referred to as $\mathrm{N}_{\mathrm{m}}$, are highly prevalent in rRNA and tRNA (Modomics database; Boccaletto et al. 2018) and are also found immediately adjacent to the $m^{7} G$ mRNA cap (Furuichi et al. 1975). Recent studies have suggested that they are present at internal sites in mRNA in yeast (Bartoli et al. 2018) and potentially in mammalian cells (Dai et al. 2017).

The initial experiments that pointed to the presence of abundant $\mathrm{N}_{\mathrm{m}}$ at internal sites were performed in mammalian cells. Using a high-throughput sequencing-based approach termed $\mathrm{N}_{\mathrm{m}}$-seq, the investigators mapped $3515 \mathrm{~N}_{\mathrm{m}}$ sites internally in mRNA and ncRNA (Dai et al. 2017). $\mathrm{N}_{\mathrm{m}^{-}}$ seq exploits a unique feature of $\mathrm{N}_{\mathrm{m}}$ (i.e., the lack of a $2^{\prime}$ hydroxyl) to map $\mathrm{N}_{\mathrm{m}}$. In this approach, periodate is used to oxidize $3^{\prime}$-terminal nucleotides of RNAs that contain hydroxyl groups at both the $2^{\prime}$ and $3^{\prime}$ positions on the ribose portion of the nucleotide. Coupled with removal of the $3^{\prime}$ terminal phosphate, this process removes the $3^{\prime}$-terminal nucleotide. However, if the terminal nucleotide contains a $2^{\prime}$-O-methyl, the $3^{\prime}$ end is protected from this reaction. To map $\mathrm{N}_{\mathrm{m}}$, the investigators therefore fragmented poly(A) RNA and subjected it to multiple rounds of elimination. This led to an enrichment of RNA fragment $3^{\prime}$ ends at $\mathrm{N}_{\mathrm{m}}$ sites that could be detected by high-throughput sequencing (Dai et al. 2017).

The validity of the original $\mathrm{N}_{\mathrm{m}}$-seq data has been questioned, as many mapped $\mathrm{N}_{\mathrm{m}}$ sites were nearly identical to the sequence of the $3^{\prime}$ adapter used for preparing the RNA library (Grozhik and Jaffrey 2018). This type of sequencing result is usually the result of a "mispriming" artifact in which the primers used for reverse transcription inadvertently amplify sequences within unligated RNA, as previously observed in CLIP libraries (Gillen et al. 2016). Consequently, a corrigendum with a revised protocol was subsequently published, reporting a new set of putative $\mathrm{N}_{\mathrm{m}}$ sites (Dai et al. 2018). Notably, the new sites were not enriched in any consensus motif. Also, the predicted sites did not cluster in any specific region of mRNAs, and no function was proposed for these modifications. None of the $\mathrm{N}_{\mathrm{m}}$ sites were individually biochemically validated, making the false-positive rate of this mapping technology currently unknown.

In contrast to the $\mathrm{N}_{\mathrm{m}}$ mapping results in human cells, a recent study showed that $\mathrm{N}_{\mathrm{m}}$ sites in yeast mRNA are in sequence contexts that match the consensus sequences associated with $\mathrm{N}_{\mathrm{m}}$ in rRNA and tRNA. Notably, the $\mathrm{N}_{\mathrm{m}}$ sites in yeast were mapped using a different approach (Bartoli et al. 2018). This approach exploits the property of reverse transcriptases to pause or stall at $\mathrm{N}_{\mathrm{m}}$ when nucleotides or magnesium are limiting. This method, termed MeTH-seq (sequencing of methylations at two prime hydroxyls), allowed the identification of thousands of RT pause sites on yeast mRNA (Bartoli et al. 2018). Importantly, to call an RT pause site identified by MeTH-seq as a potential site of $2^{\prime}$-O-methyl modification, it had to disappear in a tRNA or rRNA 2'-O-methyltransferase knockout strain. This strategy identified $690 \mathrm{~N}_{\mathrm{m}}$ sites in yeast mRNAs and assigned them to a methyltransferase enzyme that installs it. In many cases, the $\mathrm{N}_{\mathrm{m}}$ sites were found in mRNA within sequence motifs that match consensus sites seen in tRNA or ribosomal RNA, further supporting the idea that $\mathrm{N}_{\mathrm{m}}$ sites are generated by the methyltransferases normally thought to target tRNA or rRNA. This markedly contrasts with the $\mathrm{N}_{\mathrm{m}}$ sites mapped in mammalian cells, which lack evidence for tRNA or rRNA-like $\mathrm{N}_{\mathrm{m}}$ sequence motifs (Dai et al. 2018).

Notably, a subset of the yeast $\mathrm{N}_{\mathrm{m}}$ sites was dependent on the rRNA methyltransferase Spb1. These sites were mapped to mRNAs encoding ribosomal proteins. In addition, Spb1 was necessary to maintain high expression levels of these transcripts, prompting the investigators to hypothesize that the 2'-O-methylation of rRNA and ribosomal protein mRNAs might promote the formation of a regulon that spans different classes of RNAs. Another important finding was that levels of $\mathrm{N}_{\mathrm{m}}$ in mRNA appear to be regulated. Using MeTH-seq, several thousand sites were identified that were differentially methylated in cells undergoing exponential growth versus postdiauxic growth. This variation raises the possibility that different cellular states might mediate their effects by altering $\mathrm{N}_{\mathrm{m}}$ levels in cellular RNA. It will be important to establish how the signals influence $\mathrm{N}_{\mathrm{m}}$ levels, and if $\mathrm{N}_{\mathrm{m}}$ also shows dynamic variations in mammalian cells.

\subsubsection{Metabolic Labeling of $\mathrm{N}_{m}$}

Another recently developed approach to map methylated nucleotides is to identify the targets of methyltransferase 
enzymes by using a modified precursor of $S$-adenosylmethionine, the cosubstrate that is the methyl donor in nucleotide methylation reactions (Hartstock et al. 2018). In this approach, a $S$-adenosyl-methionine analog that contains propargyl-L-selenohomocysteine in place of methionine is used. This causes a propargyl group, rather than a methyl group, to be added to nucleotides (Fig. 2B, left panel). The propargyl group can then be conjugated to biotin by "click"-chemistry, enabling the purification of the targets of any RNA methyltransferase that can use this $S$-adenosylmethionine analog. This method was used to label $\mathrm{N}_{\mathrm{m}}$ in HeLa cell rRNA. In addition, the investigators have shown that this approach can be used to identify $\mathrm{m}^{6} \mathrm{~A}$ methyltransferase targets in vitro, indicating that it could be developed into a method to label various ribose and base modifications in cells.

\subsection{Other Internal Modified Nucleotides in mRNA}

A variety of other modified nucleotides might be present in mRNA. Although most of the early chromatography-based studies from the 1970s did not detect additional modified nucleotides beyond $\mathrm{m}^{6} \mathrm{~A}$, these may have been present at levels that were too low to detect. It is important to note that although these modifications may be rare, they might still have important regulatory functions. Additionally, any modified nucleotide that is highly transient, associated with rapid mRNA decay, or present only in certain disease or stress states, would not have been identified in these earlier studies.

One such modification is $\mathrm{m}^{7} \mathrm{G} \cdot \mathrm{m}^{7} \mathrm{G}$ is typically thought of as a nucleotide found at the mRNA cap structure. However, recent liquid chromatography-tandem mass spectrometry analyses of purified poly(A) RNA prepared from human and plant cells and rat tissues show that $m^{7} G$ is present internally in mRNA (Chu et al. 2018). The levels of $m^{7} G$ were found to be altered in rice exposed to heavy metals, raising the possibility that this modification could be regulated.

Another RNA modification is 8-oxo-G. Unlike the modifications described above, which are introduced via specific nucleotide-modifying enzymes, 8-oxo-G is formed as a result of oxidative stress. The DNA version of this modified nucleotide, 8-oxo-dG, is commonly used as a marker of oxidative stress. However, RNA is also susceptible to oxidation, and 8-oxo-G is detected in purified mRNA fraction using 8-oxo-G antibodies (Li et al. 2006; Shan et al. 2003). As for $\mathrm{m}^{7} \mathrm{G}$, single-nucleotide resolution maps of 8-oxo-G are not yet available.

The function of 8 -oxo-G and RNA is not known. Some studies suggest that 8 -oxo-G induces translational impairment, which would subsequently lead to no-go decay
(Simms et al. 2014). Whether 8-oxo-G preferentially forms in specific mRNAs, and whether 8-oxo-G has any specific effect on mRNA besides impairing translation and subsequently inducing degradation is not yet known.

5-hydroxymethylcytosine $\left(\mathrm{hm}^{5} \mathrm{C}\right)$ can be formed in RNA by the oxidization of $\mathrm{m}^{5} \mathrm{C}$ by deoxygenases of the Ten-eleven translocation (Tet) family (Fu et al. 2014). The first transcriptome-wide approach to map $\mathrm{hm}^{5} \mathrm{C}$ was performed in Drosophila melanogaster (Delatte et al. 2016). In an approach termed hMeRIP-seq (hydroxymethylated RNA immunoprecipitation followed by sequencing), the investigators use an $\mathrm{hm}^{5} \mathrm{C}$-specific antibody to enrich modified RNA fragments and then use a peak calling approach to identify regions containing $\mathrm{hm}^{5} \mathrm{C}$. These $\mathrm{hm}^{5} \mathrm{C}$-containing regions were found to be slightly enriched in the CDS and were proposed to restore translation of mRNAs whose translation was otherwise inhibited by the $5 \mathrm{mC}$.

A recent study investigating the function of the Tet2 dioxygenase in mice used bisulfite sequencing to identify $\mathrm{m}^{5} \mathrm{C}$ sites that were not converted to $5 \mathrm{hmC}$ in Tet 2 knockout animals (Shen et al. 2018). This revealed that $\mathrm{m}^{5} \mathrm{C}$ and $\mathrm{hm}^{5} \mathrm{C}$ might be used to control mRNA secondary structure and thereby regulate recognition by RNA binding proteins during the immune response (Shen et al. 2018).

The abundance of $5 \mathrm{hmC}$ in Drosophila mRNA has been challenged based on the inability to detect this modification using mass spectrometry analysis of highly purified Drosophila mRNA (Legrand et al. 2017). However, as with other mapping approaches, direct biochemical measurements of $5 \mathrm{hmC}$ at specific sites can resolve these controversies and establish the false-positive rate of these mapping methods to assess the overall prevalence and stoichiometry of this modification in mRNA.

\section{MAPPING THE CAP EPITRANSCRIPTOME}

\section{$5.1 \mathrm{~m}^{7} \mathrm{G}$ and $\mathrm{N}_{\mathrm{m}}$ in the Extended mRNA Cap}

Although much of the recent interest in epitranscriptomics has focused on modified nucleotides located at internal sites (i.e., between the mRNA cap and the poly(A) tail), the level of RNA modification is considerably higher at the mRNA cap compared with internal sites. Besides $\mathrm{m}^{6} \mathrm{~A}$, there are four other abundant methyl modifications in mRNA. These are the $\mathrm{N}-7$ methyl in the $\mathrm{m}^{7} \mathrm{G}$ cap, the two $2^{\prime}$-O-methyl modifications that are found at the first and second templated nucleotides, and the $N^{6}$-methyl that is found along with a $2^{\prime}$-O-methyl in $\mathrm{m}^{6} \mathrm{~A}_{\mathrm{m}}$ that can be found at the first templated nucleotide. Together, these methyl marks comprise the five major methyl modifications in mRNA.

As of yet, no transcriptome-wide analysis has been reported for the methyl modification in the $m^{7} G$ cap or 
the 2'-O-methyl modifications at the first and second templated nucleotides. Nevertheless, there is evidence that these modifications might be regulated. In the case of $m^{7} G$, the enzyme that methylates the guanosine to N7-methylguanosine, RNMT, is regulated in cancer, and overexpression of RNMT promotes cancer development (Cowling 2010a, 2010b). This suggests that under normal conditions, some mRNAs are not efficiently methylated to form the $\mathrm{m}^{7} \mathrm{G}$ cap, and expression of RNMT allows these mRNAs to mature to acquire a fully functional $\mathrm{m}^{7} \mathrm{G}$ cap. Because the $\mathrm{m}^{7} \mathrm{G}$ cap is needed for mRNA nuclear export (InestaVaquera and Cowling 2017), the unmethylated guanosinecapped mRNAs may be retained in the nucleus or degraded.

The cap-associated 2'-O-methyl modifications may also be regulated. It should be noted that some mRNAs may lack the $2^{\prime}$-O-methyl modifications altogether. These mRNAs are referred to as cap 0 . Other mRNAs may only have the $2^{\prime}$-O-methyl modification on the first encoded nucleotide, but not the second (referred to as "cap 1"). This 2'-O-methyl modification is installed by CMTR1, which requires a $\mathrm{m}^{7} \mathrm{G}$-capped RNA as a substrate (Bélanger et al. 2010; Inesta-Vaquera and Cowling 2017). CMTR1 is physically associated with RNA Pol II (Haline-Vaz et al. 2008), which suggests that this modification may be cotranscriptionally introduced into mRNA.

mRNAs may also have both the first and second transcribed nucleotide methylated at the 2'-hydroxyl, which is referred to as cap 2 (Furuichi et al. 1975). mRNAs are not likely to have only the second templated nucleotide $2^{\prime}$ $O$-methylated because CMTR2, the enzyme that introduces the $2^{\prime}$-O-methyl on the second nucleotide shows increased methyltransferase activity toward capped mRNA with a 2'-O-methyl on the first nucleotide (Werner et al. 2011).

One major function of $2^{\prime}-O$-methylation is that this modification may contribute to an antiviral defense pathway. Viral infection is associated with the induction of CMTR1 which converts cap 0 RNAs to cap 1 and potentially cap 2 mRNAs (Daffis et al. 2010; Züst et al. 2011). The presence of 2'-O-methyl modifications prevents these mRNAs from binding IFIT proteins, which are induced by interferon in response to viral infection (Fensterl and Sen 2015). IFITs bind their target mRNAs at the extended cap structure and suppress translation by competing for binding by cap-binding proteins (Habjan et al. 2013; Kimura et al. 2013). Thus, $2^{\prime}-O$-methylation protects host mRNAs from the antiviral response, which is intended to be directed toward viral RNAs.

However, 2'-O-methylation is detected in cells even in the absence of viral infection, and the levels of cap 1 and cap 2 appear to differ between cells (Furuichi et al. 1975). Thus, $2^{\prime}$-O-methylation at the cap may have functions even in the absence of viral infection. As of yet, the distribution of
2'-O-methyl modifications associated with mRNA caps has not been mapped in the transcriptome.

\section{$5.2 \mathrm{~m}^{6} \mathrm{Am}$}

The only cap-associated methylation that has been profiled on a transcriptome-wide level is $\mathrm{m}^{6} \mathrm{Am} . \mathrm{m}^{6} \mathrm{Am}$ is mapped simultaneously with $\mathrm{m}^{6} \mathrm{~A}$ in the $\mathrm{m}^{6} \mathrm{~A}$ miCLIP protocol (described above), which uses an $\mathrm{m}^{6} \mathrm{~A}$ antibody. $\mathrm{m}^{6} \mathrm{~A}$ antibodies also bind $\mathrm{m}^{6} \mathrm{Am}$ (Munns et al. 1979) and therefore are more accurately described as 6-methyladenine antibodies to reflect their binding to the two 6-methyladenine-containing nucleotides, $\mathrm{m}^{6} \mathrm{~A}$ and $\mathrm{m}^{6} \mathrm{Am}$.

Before the development of miCLIP, $\mathrm{m}^{6} \mathrm{~A}$ and $\mathrm{m}^{6} \mathrm{Am}$ could not be distinguished. Therefore MeRIP-seq peaks found in the $5^{\prime}$ UTR could not be easily assigned as an $\mathrm{m}^{6} \mathrm{~A}$ or an $\mathrm{m}^{6} \mathrm{Am}$. Conceivably the location of the MeRIPseq peak within the $5^{\prime}$ UTR could hint that it reflects an $m^{6} \mathrm{~A}$, rather than an $\mathrm{m}^{6} \mathrm{Am}$, which is exclusively found at the transcription-start nucleotide. A peak in the middle of the $5^{\prime}$ UTR is clearly not at the transcription-start nucleotide. Unfortunately, this reasoning is not valid. Many transcripts have alternative transcription start sites, some of which may be downstream from annotated transcription start sites (Shiraki et al. 2003). Therefore, an $\mathrm{m}^{6} \mathrm{Am}$ from an isoform with a shorter $5^{\prime}$ UTR than the annotated $5^{\prime}$ UTR isoform will produce a peak that appears to be in the middle of the annotated $5^{\prime}$ UTR despite the fact that it is located at the transcription-start site of a different mRNA isoform.

In MeRIP-seq, RNA fragments are immunoprecipitated, and the RNA is reverse transcribed to make the first strand of cDNA. Next, the second strand of cDNA is made by nicking the RNA and using the free end as a primer for DNA synthesis. In this protocol, the $5^{\prime}$ end of the RNA is not preserved, because the second strand of cDNA starts somewhat randomly based on the position of the nick.

In the case of $\mathrm{m}^{6} \mathrm{~A}$, the lack of preservation of the $5^{\prime}$ end is not important because $\mathrm{m}^{6} \mathrm{~A}$ can be anywhere in the immunoprecipitated RNA. Therefore, the $\mathrm{m}^{6} \mathrm{~A}$ will still be in the middle of the resulting peak. However, for $\mathrm{m}^{6} \mathrm{Am}$, the RNA fragments will be different-in each case, the $m^{6} \mathrm{Am}$ will always be exactly at the $5^{\prime}$ end of the RNA. Therefore, the loss of the $5^{\prime}$ end means that the MeRIPseq will be positioned downstream from the actual site of the $\mathrm{m}^{6} \mathrm{Am}$. The peak will look like an $\mathrm{m}^{6} \mathrm{~A}$ peak downstream from the actual site of the $\mathrm{m}^{6} \mathrm{Am}$.

miCLIP overcomes this problem by preserving the exact $5^{\prime}$ end of immunoprecipitated RNAs. Because all reads that contain $\mathrm{m}^{6} \mathrm{Am}$ will have the same $5^{\prime}$ end (i.e., the transcription start nucleotide), this will result in the appearance of a "cliff" or edge that clearly demarcates the position of $\mathrm{m}^{6} \mathrm{Am}$. 
Library methods that preserve the $5^{\prime}$ end of RNAs reduce the ambiguity of assigning a peak to $\mathrm{m}^{6} \mathrm{~A}$ or $\mathrm{m}^{6} \mathrm{Am}$.

Based on the mapping of $\mathrm{m}^{6} \mathrm{Am}$ using miCLIP, a function for $\mathrm{m}^{6} \mathrm{Am}$ could be identified. Our analysis showed that $\mathrm{m}^{6} \mathrm{Am}$-containing mRNAs show longer mRNA halflives than mRNAs that begin with other nucleotides. The stability of $\mathrm{m}^{6} \mathrm{Am}$ appears to be mediated, at least in part, by reduced susceptibility of $\mathrm{m}^{6} \mathrm{Am}$-containing mRNAs to decapping. Biochemical analysis of RNAs containing $\mathrm{m}^{6} \mathrm{Am}$ showed that they were decapped by the Dcp2 decapping enzyme with markedly reduced efficiency compared with similar RNAs that contained Am. Thus, a single N-6 methyl modification causes the RNA to show reduced decapping. Notably, $m^{6} A m$ mRNAs also show reduced susceptibility to microRNAs, which induce a decapping step as part of their mechanism to induce RNA degradation. Thus, $\mathrm{m}^{6} \mathrm{Am}$ may have a role in stabilizing mRNAs.

At present, the enzyme that forms $\mathrm{m}^{6} \mathrm{Am}$ from Am has been biochemically purified (Keith et al. 1978) but not yet cloned. Identification of this enzyme will enable a more comprehensive analysis of the function of this modification in mRNA. Additionally, the "readers" of $\mathrm{m}^{6} \mathrm{Am}$ are not yet known, but they may contribute to the mechanism of $\mathrm{m}^{6} \mathrm{Am}$-mediated translational enhancement or other effects of $\mathrm{m}^{6} \mathrm{Am}$.

\section{CONCLUDING REMARKS AND FURTHER DIRECTIONS}

As the field moves forward a major emphasis is validating modification sites that are predicted by mapping studies. Although it is likely that certain transcripts contain $\mathrm{m}^{5} \mathrm{C}$, $\mathrm{m}^{1} \mathrm{~A}$, and $\mathrm{N}_{\mathrm{m}}$ in mammalian transcriptomes, it is not clear how many of the sites predicted by mapping methods reflect actual modification sites or reflect noise inherent in these assays. Methods such as SCARLET (Liu et al. 2013), which can detect the amounts of modified and nonmodified nucleotide in a site-specific manner in mRNAs, will be useful to detect modified nucleotides at specific sites.

In the case of $\mathrm{m}^{6} \mathrm{~A}, \mathrm{~m}^{6} \mathrm{~A}_{\mathrm{m}}$, and pseudouridine, a major goal will be to move from simple mapping methods to new approaches that reveal the stoichiometry of these modifications. Newer methods for transcriptome-wide quantification of the stoichiometry of these modifications are needed to determine how these modifications are regulated at each site in the transcriptome in disease states and in response to signaling pathways.

Lastly, a major underexplored area of investigation is the three unmapped methyl modifications in the mRNA cap structure-that is, the methyl group in the $\mathrm{m}^{7} \mathrm{G}$ and the $2^{\prime}$-O-methyl modifications at the first and second templated nucleotide. Mapping studies for these modifications will be important for determining if these modifications are dynamic and encode epitranscriptomic information that determines the fate of mRNAs in the cell.

\section{ACKNOWLEDGMENTS}

This work was supported by National Institutes of Health (NIH) Grants R01DA037755 and R01CA186702 (S.R.J.) and German Research Foundation (DFG) research fellowship LI 2385/1-1 (B.L.).

\section{REFERENCES}

Amort T, Soulière MF, Wille A, Jia X-Y, Fiegl H, Wörle H, Micura R, Lusser A. 2013. Long non-coding RNAs as targets for cytosine methylation. RNA Biol 10: 1002-1008.

Bartoli KM, Schaening C, Carlile T, Gilbert WV. 2018. Conserved methyltransferase Spb1 targets mRNAs for regulated modification with 2'-O-methyl ribose. bioRxiv doi: 10.1101/271916.

Beemon K, Keith J. 1977. Localization of $N^{6}$-methyladenosine in the Rous sarcoma virus genome. J Mol Biol 113: 165-179.

Bélanger F, Stepinski J, Darzynkiewicz E, Pelletier J. 2010. Characterization of hMTr1, a human Cap1 2'-O-ribose methyltransferase. J Biol Chem 285: 33037-33044.

Boccaletto P, Machnicka MA, Purta E, Piątkowski P, Bagiński B, Wirecki TK, de Crécy-Lagard V, Ross R, Limbach PA, Kotter A, et al. 2018. MODOMICS: A database of RNA modification pathways. 2017 update. Nucleic Acids Res 46: D303-D307.

Carlile TM, Rojas-Duran MF, Zinshteyn B, Shin H, Bartoli KM, Gilbert WV. 2014. Pseudouridine profiling reveals regulated mRNA pseudouridylation in yeast and human cells. Nature 515: 143-146.

Chu J-M, Ye T-T, Ma C-J, Lan M-D, Liu T, Yuan B-F, Feng Y-Q. 2018. Existence of internal $N^{7}$-methylguanosine modification in mRNA determined by differential enzyme treatment coupled with mass spectrometry analysis. ACS Chem Biol doi: 10.1021/acschembio.7b00906.

Cowling VH. 2010a. Enhanced mRNA cap methylation increases cyclin D1 expression and promotes cell transformation. Oncogene 29: 930936.

Cowling VH. 2010b. Myc up-regulates formation of the mRNA methyl cap. Biochem Soc Trans 38: 1598-1601.

Cui P, Lin Q, Ding F, Xin C, Gong W, Zhang L, Geng J, Zhang B, Yu X, Yang J, et al. 2010. A comparison between ribo-minus RNA-sequencing and polyA-selected RNA-sequencing. Genomics 96: 259-265.

Daffis S, Szretter KJ, Schriewer J, Li J, Youn S, Errett J, Lin T-Y, Schneller S, Zust R, Dong H, et al. 2010. 2'-O methylation of the viral mRNA cap evades host restriction by IFIT family members. Nature 468: 452-456.

Dai Q, Moshitch-Moshkovitz S, Han D, Kol N, Amariglio N, Rechavi G, Dominissini D, He C. 2017. Nm-seq maps 2'-O-methylation sites in human mRNA with base precision. Nat Methods 14: 695-698.

Dai Q, Moshitch-Moshkovitz S, Han D, Kol N, Amariglio N, Rechavi G, Dominissini D, He C. 2018. Corrigendum: Nm-seq maps $2^{\prime}$-O-methylation sites in human mRNA with base precision. Nat Methods 15: 226-227.

Davis DR. 1995. Stabilization of RNA stacking by pseudouridine. Nucleic Acids Res 23: 5020-5026.

Delatte B, Wang F, Ngoc LV, Collignon E, Bonvin E, Deplus R, Calonne E, Hassabi B, Putmans P, Awe S, et al. 2016. Transcriptome-wide distribution and function of RNA hydroxymethylcytosine. Science 351: $282-285$.

Dominissini D, Moshitch-Moshkovitz S, Schwartz S, Salmon-Divon M, Ungar L, Osenberg S, Cesarkas K, Jacob-Hirsch J, Amariglio N, Kupiec $\mathrm{M}$, et al. 2012. Topology of the human and mouse m6A RNA methylomes revealed by m6A-seq. Nature 485: 201-206. 
Dominissini D, Nachtergaele S, Moshitch-Moshkovitz S, Peer E, Kol N, Ben-Haim MS, Dai Q, Di Segni A, Salmon-Divon M, Clark WC, et al. 2016. The dynamic $N^{1}$-methyladenosine methylome in eukaryotic messenger RNA. Nature 530: 441-446.

Dubin DT, Taylor RH. 1975. The methylation state of poly A-containing messenger RNA from cultured hamster cells. Nucleic Acids Res 2: 1653-1668.

Edelheit S, Schwartz S, Mumbach MR, Wurtzel O, Sorek R. 2013. Transcriptome-wide mapping of 5-methylcytidine RNA modifications in bacteria, archaea, and yeast reveals m5C within archaeal mRNAs. PLOS Genet 9: e1003602.

Fensterl V, Sen GC. 2015. Interferon-induced Ifit proteins: Their role in viral pathogenesis. J Virol 89: 2462-2468.

Friderici K, Kaehler M, Rottman F. 1976. Kinetics of Novikoff cytoplasmic messenger RNA methylation. Biochemistry 15: 5234-5241.

Frommer M, McDonald LE, Millar DS, Collis CM, Watt F, Grigg GW, Molloy PL, Paul CL. 1992. A genomic sequencing protocol that yields a positive display of 5-methylcytosine residues in individual DNA strands. Proc Natl Acad Sci 89: 1827-1831.

Fu L, Guerrero CR, Zhong N, Amato NJ, Liu Y, Liu S, Cai Q, Ji D, Jin S-G, Niedernhofer LJ, et al. 2014. Tet-mediated formation of 5-hydroxymethylcytosine in RNA. J Am Chem Soc 136: 11582-11585.

Furuichi Y, Morgan M, Shatkin AJ, Jelinek W, Salditt-Georgieff M, Darnell JE. 1975. Methylated, blocked 5 termini in HeLa cell mRNA. Proc Natl Acad Sci 72: 1904-1908.

Gillen AE, Yamamoto TM, Kline E, Hesselberth JR, Kabos P. 2016. Improvements to the HITS-CLIP protocol eliminate widespread mispriming artifacts. BMC Genomics 17: 338.

Gokhale NS, Horner SM. 2017. RNA modifications go viral. PLoS Pathog 13: e1006188.

Grozhik AV, Jaffrey SR. 2017. Epitranscriptomics: Shrinking maps of RNA modifications. Nature 551: 174-176.

Grozhik AV, Jaffrey SR. 2018. Distinguishing RNA modifications from noise in epitranscriptome maps. Nat Chem Biol 14: 215-225.

Habjan M, Hubel P, Lacerda L, Benda C, Holze C, Eberl CH, Mann A, Kindler E, Gil-Cruz C, Ziebuhr J, et al. 2013. Sequestration by IFIT1 impairs translation of $2^{\prime} \mathrm{O}$-unmethylated capped RNA. PLoS Pathog 9: e1003663.

Haline-Vaz T, Lima Silva TC, Zanchin NIT. 2008. The human interferonregulated ISG95 protein interacts with RNA polymerase II and shows methyltransferase activity. Biochem Biophys Res Commun 372: 719724 .

Hartstock K, Nilges Benedikt S, Ovcharenko A, Cornelissen Nicolas V, Püllen N, Lawrence-Dörner A-M, Leidel Sebastian A, Rentmeister A. 2018. Enzymatic or in vivo installation of propargyl groups in combination with click chemistry for the enrichment and detection of methyltransferase target sites in RNA. Angew Chem Int Ed 21: 6342-6346.

Hauenschild R, Tserovski L, Schmid K, Thüring K, Winz M-L, Sharma S, Entian K-D, Wacheul L, Lafontaine DLJ, Anderson J, et al. 2015. The reverse transcription signature of $N$-1-methyladenosine in RNA-seq is sequence dependent. Nucleic Acids Res 43: 9950-9964.

Ho NWY, Gilham PT. 1971. Reaction of pseudouridine and inosine with $N$-cyclohexyl- $N^{\prime}-\beta$-(4-methylmorpholinium) ethylcarbodiimide. Biochemistry 10: 3651-3657.

Hussain S, Sajini AA, Blanco S, Dietmann S, Lombard P, Sugimoto Y, Paramor M, Gleeson JG, Odom DT, Ule J, et al. 2013. NSun2-mediated cytosine-5 methylation of vault noncoding RNA determines its processing into regulatory small RNAs. Cell Rep 4: 255-261.

Inesta-Vaquera F, Cowling VH. 2017. Regulation and function of CMTR1-dependent mRNA cap methylation. Wiley Interdiscip Rev RNA 8: e1450.

Jaffrey SR, Kharas MG. 2017. Emerging links between $\mathrm{m}^{6} \mathrm{~A}$ and misregulated mRNA methylation in cancer. Genome Med 9: 2.

Karikó K, Muramatsu H, Welsh FA, Ludwig J, Kato H, Akira S, Weissman D. 2008. Incorporation of pseudouridine into mRNA yields superior nonimmunogenic vector with increased translational capacity and biological stability. Mol Ther 16: 1833-1840.
Keith JM, Ensinger MJ, Mose B. 1978. HeLa cell RNA (2'-O-methyladenosine- $N^{6}$-)-methyltransferase specific for the capped $5^{\prime}$-end of messenger RNA. J Biol Chem 253: 5033-5039.

Khoddami V, Cairns BR. 2013. Identification of direct targets and modified bases of RNA cytosine methyltransferases. Nat Biotechnol 31: 458-464.

Kimura T, Katoh H, Kayama H, Saiga H, Okuyama M, Okamoto T, Umemoto E, Matsuura Y, Yamamoto M, Takeda K. 2013. Ifit1 inhibits Japanese encephalitis virus replication through binding to $5^{\prime}$ capped $2^{\prime}$ O unmethylated RNA. J Virol 87: 9997-10003.

Klungland A, Dahl JA, Greggains G, Fedorcsak P, Filipczyk A. 2017. Reversible RNA modifications in meiosis and pluripotency. Nat Methods 14: 18-22.

Legrand C, Tuorto F, Hartmann M, Liebers R, Jacob D, Helm M, Lyko F. 2017. Statistically robust methylation calling for whole-transcriptome bisulfite sequencing reveals distinct methylation patterns for mouse RNAs. Genome Res 27: 1589-1596.

Li Z, Wu J, Deleo CJ. 2006. RNA damage and surveillance under oxidative stress. IUBMB Life 58: 581-588.

Li X, Zhu P, Ma S, Song J, Bai J, Sun F, Yi C. 2015. Chemical pulldown reveals dynamic pseudouridylation of the mammalian transcriptome. Nat Chem Biol 11: 592-597.

Li X, Xiong X, Wang K, Wang L, Shu X, Ma S, Yi C. 2016. Transcriptomewide mapping reveals reversible and dynamic $N^{1}$-methyladenosine methylome. Nat Chem Biol 12: 311-316.

Li X, Xiong X, Zhang M, Wang K, Chen Y, Zhou J, Mao Y, Lv J, Yi D, Chen $\mathrm{X}-\mathrm{W}$, et al. 2017. Base-resolution mapping reveals distinct $\mathrm{m}^{1} \mathrm{~A}$ methylome in nuclear- and mitochondrial-encoded transcripts. Mol Cell 68: 993-1005.e9.

Linder B, Grozhik AV, Olarerin-George AO, Meydan C, Mason CE, Jaffrey SR. 2015. Single-nucleotide-resolution mapping of m6A and m6Am throughout the transcriptome. Nat Methods 12: 767-772.

Liu Y, Santi DV. 2000. m5C RNA and m5C DNA methyl transferases use different cysteine residues as catalysts. Proc Natl Acad Sci 97: 82638265.

Liu N, Parisien M, Dai Q, Zheng G, He C, Pan T. 2013. Probing $N^{6}$ methyladenosine RNA modification status at single nucleotide resolution in mRNA and long noncoding. RNA 19: 1848-1856.

Lovejoy AF, Riordan DP, Brown PO. 2014. Transcriptome-wide mapping of pseudouridines: Pseudouridine synthases modify specific mRNAs in S. cerevisiae. PLoS ONE 9: e110799.

Meyer KD, Saletore Y, Zumbo P, Elemento O, Mason CE, Jaffrey SR. 2012. Comprehensive analysis of mRNA methylation reveals enrichment in 3' UTRs and near stop codons. Cell 149: 1635-1646.

Munns TW, Oberst RJ, Sims HF, Liszewski MK. 1979. Antibody-nucleic acid complexes. Immunospecific recognition of 7-methylguanine- and $N^{6}$-methyladenine-containing $5^{\prime}$-terminal oligonucleotides of mRNA. J Biol Chem 254: 4327-4330.

Perry RP, Kelley DE, Friderici K, Rottman F. 1975. The methylated constituents of L cell messenger RNA: Evidence for an unusual cluster at the $5^{\prime}$ terminus. Cell 4: 387-394.

Ryvkin P, Leung YY, Silverman IM, Childress M, Valladares O, Dragomir I, Gregory BD, Wang L-S. 2013. HAMR: High-throughput annotation of modified ribonucleotides. RNA 19: 1684-1692.

Safra M, Sas-Chen A, Nir R, Winkler R, Nachshon A, Bar-Yaacov D, Erlacher M, Rossmanith W, Stern-Ginossar N, Schwartz S. 2017. The $\mathrm{m}^{1} \mathrm{~A}$ landscape on cytosolic and mitochondrial mRNA at single-base resolution. Nature 551: 251-255.

Schaefer M, Pollex T, Hanna K, Lyko F. 2009. RNA cytosine methylation analysis by bisulfite sequencing. Nucleic Acids Res 37: e12.

Schibler U, Kelley DE, Perry RP. 1977. Comparison of methylated sequences in messenger RNA and heterogeneous nuclear RNA from mouse L cells. J Mol Biol 115: 695-714.

Schwartz S, Bernstein DA, Mumbach MR, Jovanovic M, Herbst RH, León-Ricardo BX, Engreitz JM, Guttman M, Satija R, Lander ES, et al. 2014. Transcriptome-wide mapping reveals widespread dynamic-regulated pseudouridylation of ncRNA and mRNA. Cell 159: 148-162. 
B. Linder and S.R. Jaffrey

Shan X, Tashiro H, Lin CG. 2003. The identification and characterization of oxidized RNAs in Alzheimer's disease. J Neurosci 23: 4913-4921.

Shen Q, Zhang Q, Shi Y, Shi Q, Jiang Y, Gu Y, Li Z, Li X, Zhao K, Wang C, et al. 2018. Tet2 promotes pathogen infection-induced myelopoiesis through mRNA oxidation. Nature 554: 123-127.

Shimba S, Bokar JA, Rottman F, Reddy R. 1995. Accurate and efficient $\mathrm{N}$-6-adenosine methylation in spliceosomal U6 small nucelar RNA by HeLa cell extract in vitro. Nucleic Acids Res 23: 2421-2426.

Shiraki T, Kondo S, Katayama S, Waki K, Kasukawa T, Kawaji H, Kodzius R, Watahiki A, Nakamura M, Arakawa T, et al. 2003. Cap analysis gene expression for high-throughput analysis of transcriptional starting point and identification of promoter usage. Proc Natl Acad Sci 100: 15776-15781.

Simms CL, Hudson BH, Mosior JW, Rangwala AS, Zaher HS. 2014. An active role for the ribosome in determining the fate of oxidized mRNA. Cell Rep 9: 1256-1264.

Sommer S, Lavi U, Darnell JE. 1978. The absolute frequency of labeled $\mathrm{N}$-6-methyladenosine in HeLa cell messenger RNA decreases with label time. J Mol Biol 124: 487-499.

Squires JE, Patel HR, Nousch M, Sibbritt T, Humphreys DT, Parker BJ, Suter CM, Preiss T. 2012. Widespread occurrence of 5-methylcytosine in human coding and non-coding RNA. Nucleic Acids Res 40: 5023-5033.

Sultan M, Amstislavskiy V, Risch T, Schuette M, Dökel S, Ralser M, Balzereit D, Lehrach H, Yaspo M-L. 2014. Influence of RNA extraction methods and library selection schemes on RNA-seq data. BMC Genomics 15: 675 .

Wei C-M, Gershowitz A, Moss B. 1975a. Methylated nucleotides block 5' terminus of HeLa cell messenger RNA. Cell 4: 379-386.

Wei C-M, Gershowitz A, Moss B. 1975b. N6, O2'-dimethyladenosine a novel methylated ribonucleoside next to the $5^{\prime}$ terminal of animal cell and virus mRNAs. Nature 257: 251-253.
Wei CM, Gershowitz A, Moss B. 1976.5' -Terminal and internal methylated nucleotide sequences in HeLa cell mRNA. Biochemistry 15: 397-401.

Werner M, Purta E, Kaminska KH, Cymerman IA, Campbell DA, Mittra B, Zamudio JR, Sturm NR, Jaworski J, Bujnicki JM. 2011. 2'-O-ribose methylation of cap2 in human: Function and evolution in a horizontally mobile family. Nucleic Acids Res 39: 4756-4768.

Weyn-Vanhentenryck SM, Mele A, Yan Q, Sun S, Farny N, Zhang Z, Xue C, Herre M, Silver PA, Zhang MQ, et al. 2014. HITS-CLIP and integrative modeling define the Rbfox splicing-regulatory network linked to brain development and autism. Cell Rep 6: 1139-1152.

Zaringhalam M, Papavasiliou FN. 2016. Pseudouridylation meets nextgeneration sequencing. Methods 107: 63-72.

Zhang C, Darnell RB. 2011. Mapping in vivo protein-RNA interactions at single-nucleotide resolution from HITS-CLIP data. Nat Biotech 29: 607-614.

Zhao W, He X, Hoadley KA, Parker JS, Hayes DN, Perou CM. 2014. Comparison of RNA-seq by poly(A) capture, ribosomal RNA depletion, and DNA microarray for expression profiling. BMC Genomics 15: 419.

Zheng G, Qin Y, Clark WC, Dai Q, Yi C, He C, Lambowitz AM, Pan T. 2015. Efficient and quantitative high-throughput tRNA sequencing. Nat Methods 12: 835.

Zhong S, Li H, Bodi Z, Button J, Vespa L, Herzog M, Fray RG. 2008. MTA is an arabidopsis messenger RNA adenosine methylase and interacts with a homolog of a sex-specific splicing factor. Plant Cell Online 20: $1278-1288$

Züst R, Cervantes-Barragan L, Habjan M, Maier R, Neuman BW, Ziebuhr J, Szretter KJ, Baker SC, Barchet W, Diamond MS, et al. 2011. Ribose 2' $\mathrm{O}$-methylation provides a molecular signature for the distinction of self and non-self mRNA dependent on the RNA sensor Mda5. Nat Immunol 12: 137-143. 


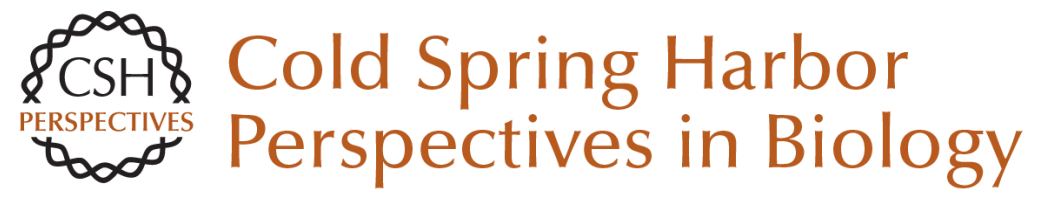

\title{
Discovering and Mapping the Modified Nucleotides That Comprise the Epitranscriptome of mRNA
}

\author{
Bastian Linder and Samie R. Jaffrey \\ Cold Spring Harb Perspect Biol 2019; doi: 10.1101/cshperspect.a032201
}

\section{Subject Collection RNA Worlds}

Alternate RNA Structures

Marie Teng-Pei Wu and Victoria D'Souza

Approaches for Understanding the Mechanisms of Long Noncoding RNA Regulation of Gene Expression

Patrick McDonel and Mitchell Guttman

Principles and Practices of Hybridization Capture

Experiments to Study Long Noncoding RNAs That

Act on Chromatin

Matthew D. Simon and Martin Machyna

Linking RNA Sequence, Structure, and Function

on Massively Parallel High-Throughput

Sequencers

Sarah K. Denny and William J. Greenleaf

Extensions, Extra Factors, and Extreme

Complexity: Ribosomal Structures Provide

Insights into Eukaryotic Translation

Melanie Weisser and Nenad Ban

Nascent RNA and the Coordination of Splicing with Transcription

Karla M. Neugebauer

Combining Mass Spectrometry (MS) and Nuclear Magnetic Resonance (NMR) Spectroscopy for Integrative Structural Biology of Protein-RNA

Complexes

Alexander Leitner, Georg Dorn and Frédéric H.-T. Allain

For additional articles in this collection, see http://cshperspectives.cshlp.org/cgi/collection/

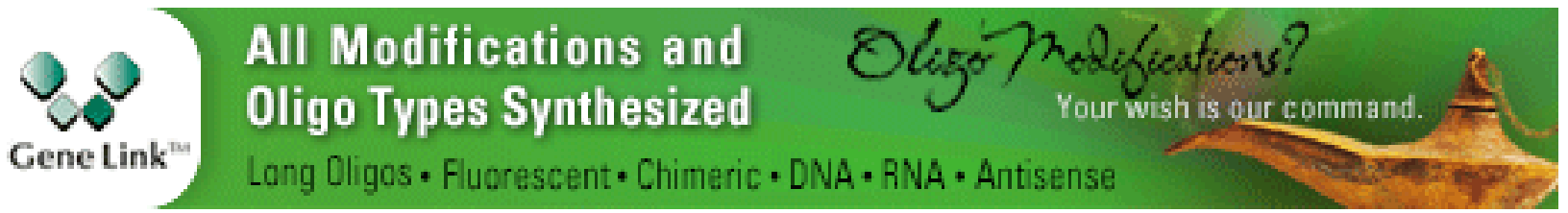

Structural Biology of Telomerase

Structural Insights into Nuclear pre-mRNA

Splicing in Higher Eukaryotes

Berthold Kastner, Cindy L. Will, Holger Stark, et al.

What Are 3' UTRs Doing?

Christine Mayr

Single-Molecule Analysis of Reverse

Transcriptase Enzymes

Linnea I. Jansson and Michael D. Stone

\section{CRISPR Tools for Systematic Studies of RNA \\ Regulation \\ Jesse Engreitz, Omar Abudayyeh, Jonathan}

Gootenberg, et al.

Relating Structure and Dynamics in RNA Biology Kevin P. Larsen, Junhong Choi, Arjun Prabhakar, et al.

Beyond DNA and RNA: The Expanding Toolbox of Synthetic Genetics

Alexander I. Taylor, Gillian Houlihan and Philipp Holliger
Yaqiang Wang, Lukas Susac and Juli Feigon

Copyright @ 2019 Cold Spring Harbor Laboratory Press; all rights reserved 
Discovering and Mapping the Modified Nucleotides That Comprise the Epitranscriptome of mRNA

Bastian Linder and Samie R. Jaffrey
Structural Basis of Nuclear pre-mRNA Splicing:

\section{Lessons from Yeast}

Clemens Plaschka, Andrew J. Newman and Kiyoshi Nagai

For additional articles in this collection, see http://cshperspectives.cshlp.org/cgi/collection/

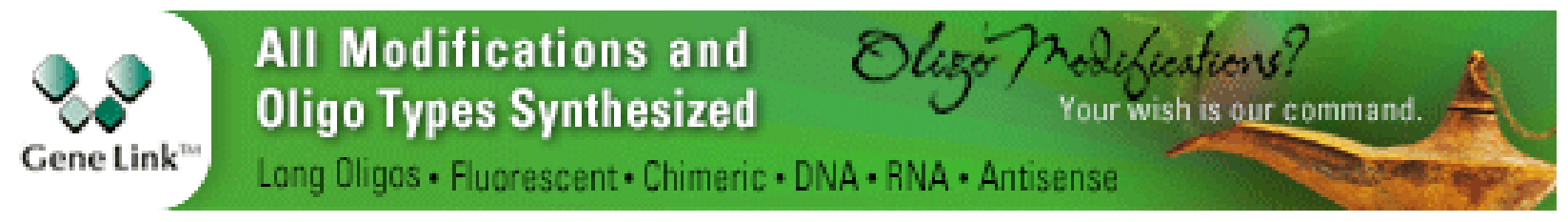

Copyright (C) 2019 Cold Spring Harbor Laboratory Press; all rights reserved 